\title{
The Limits of Model-Based Regulation
}

\author{
Markus Behn ${ }^{*} \dagger$ Rainer Haselmann ${ }^{\ddagger}$ Vikrant Vig ${ }^{\S}$
}

August 28, 2014

\begin{abstract}
In this paper, we investigate how the introduction of complex, model-based capital regulation affected credit risk of financial institutions. Model-based regulation was meant to enhance the stability of the financial sector by making capital charges more sensitive to risk. Exploiting the staggered introduction of the model-based approach in Germany and the richness of our loan-level data set, we show that (1) internal risk estimates employed for regulatory purposes systematically underpredict actual default rates by 0.5 to 1 percentage points; (2) both default rates and loss rates are higher for loans that were originated under the model-based approach, while corresponding risk-weights are significantly lower; and (3) interest rates are higher for loans originated under the model-based approach, suggesting that banks were aware of the higher risk associated with these loans and priced them accordingly. Further, we document that large banks benefited from the reform as they experienced a reduction in capital charges and consequently expanded their lending at the expense of smaller banks that did not introduce the model-based approach. Counter to the stated objectives, the introduction of complex regulation adversely affected the credit risk of financial institutions. Overall, our results highlight the pitfalls of complex regulation and suggest that simpler rules may increase the efficacy of financial regulation.
\end{abstract}

Keywords: capital regulation, internal ratings, Basel regulation

JEL Classification: G01, G21, G28

\footnotetext{
*Bonn University, Adenauerallee 24, 53113 Bonn, Germany; E-mail: behn@uni-bonn.de

†Deutsche Bundesbank, Wilhelm-Epstein-Straße 14, 60431 Frankfurt am Main, Germany

† Bonn University, Adenauerallee 24, 53113 Bonn, Germany; E-mail: rainer.haselmann@uni-bonn.de

${ }^{\S}$ London Business School, Regent's Park, London NW1 4SA, United Kingdom; E-mail: vvig@london.edu. Acknowledgements: We would like to thank Tobias Berg, Dion Bongaerts, Jörg Breitung, Joao Cocco, Jean-Edouard Colliard, Hans Degryse, Charles Goodhart, Matrin Hellwig, Victoria Ivashina, Anil Kashyap, Randy Kroszner, Fred Malherbe, John Moore, Steven Ongena, Rafael Repullo, Jean-Charles Rochet, Stephen Schaefer, Henri Servaes, Andrei Shleifer, Kelly Shue, Vania Stavrakeva, Jeremy Stein, Rene Stulz, Johannes Stroebel, Javier Suarez, Anjan Thakor, Harald Uhlig and Luigi Zingales, as well as seminar participants at Bonn University, Cass, CEMFI, Deutsche Bundesbank, London Business School, London School of Economics, NBER Summer Institute (CF/RISK, ME and CRA), University of Frankfurt, University of Leuven, University of Zurich, the Adam Smith Workshop 2013 in London, and the IMFS Conference 2013 in Frankfurt for their useful comments and discussions. We are grateful to the Deutsche Bundesbank, in particular to Klaus Düllmann and Thomas Kick, for their generous support with the construction of the data set. Birgit Maletzke and Patricia Müller provided us with valuable insights regarding the institutional details surrounding the introduction of asset-specific risk weights by German banks. Financial support from the German Research Foundation (Priority Program 1578) and the RAMD grant from LBS is acknowledged. The usual disclaimer on errors applies also applies here.
} 


\section{Introduction}

Following the financial crisis of 2008, policy makers around the world have concentrated their efforts on designing a regulatory framework that increases the safety of individual institutions as well as the stability of the financial system as a whole. While there is relatively wide agreement on the necessity of such measures, a deeper debate has evolved on the optimal level and structure of financial regulation, with the design of banks' capital charges at its core. In this context, the most important innovation in recent years has been the introduction of complex, model-based capital regulation that was meant to promote the adoption of stronger risk management practices by financial intermediaries, and-ultimately-to increase the stability of the banking system (Basel Committee on Banking Supervision 2006). While proponents of such regulation argue that a complex financial system requires complex regulation to ensure an efficient allocation of resources, critics point out that complicated and often opaque rules create high compliance costs and barriers to entry, while providing endless latitude for regulatory arbitrage.

In this paper, we examine how the introduction of model-based capital regulation affected the measurement and the overall level of banks' credit risk. Given the current focus on financial stability, this is a very important issue for both academics and regulators. Prior to the introduction of modelbased regulation, the regulatory environment was considered to be too coarse, leading to excessive distortions in lending. Bank assets were bucketed into broad risk categories and each category was subject to a flat capital charge (a flat tax). In contrast, regulation under Basel II relies on a complex array of risk models, designed and calibrated by banks themselves and subsequently approved by the supervisor. ${ }^{1}$ As a consequence, many banks have more than 100 different risk models with thousands of parameters in place, all of which require constant validation and re-calibration by the bank's risk management and surveillance by the supervisor.

Model-based regulation is based on the economic principle "He who pollutes should be taxed": The higher the risk on a specific position, the higher the capital charge. By tying capital charges to actual asset risk, banks are no longer penalized for holding very safe assets on their balance sheets, so that the distortion in the allocation of credit that accompanied the simple flat tax feature of Basel I is eliminated. In a world with no informational and enforcement problems, such a sophisticated regula-

\footnotetext{
${ }^{1}$ The latest revision of the regulatory framework, Basel III, retains the most important features of Basel II-most prominently the feature of model-based capital regulation-but introduces some corrective measures that are meant to address the most obvious problems with the previous framework.
} 
tion should unambiguously improve welfare. The conclusion, however, becomes murkier in a world with informational and incentive constraints. As argued by Glaeser and Shleifer (2001), coarser regulation can be the optimal regulatory choice and may actually dominate more sophisticated forms of regulation in the presence of enforcement constraints. Given the wide prevalence of informational and enforcement constraints in the lending process, the effect of sophisticated, model-based regulation on banks' credit risk remains an open question that we examine in this paper. $^{2}$

To study this question, we exploit the institutional details of the German Basel II introduction in 2007, as well as the high granularity of our loan-level data set obtained from Deutsche Bundesbank. Following the reform, banks were allowed to choose between the model-based approach (referred to as the internal ratings-based approach, shortened to IRB) in which capital charges depend on internal risk estimates of the bank, and a more traditional approach that does not rely on internal risk parameters (referred to as the standard approach, shortened to SA). The introduction of IRB required an extensive risk management system that had to be certified by the regulator, which imposed a significant compliance cost on the bank (Basel Committee on Banking Supervision 2004). Consequently, only very large banks found it worthwhile to introduce the new regulatory approach, while smaller regional banks opted for the standard approach to determine capital charges.

Importantly, among those banks that opted for the new approach (referred to as IRB banks), the introduction of the model-based approach was staggered over time. Risk models were certified by the supervisor on a portfolio basis, and supervisors delayed the approval of each model until they felt comfortable about the reliability of the model. ${ }^{3}$ In many cases, this meant waiting for more data on a specific portfolio of loans. We exploit this staggered implementation to identify the effects of model-based regulation within the group of IRB banks.

At the aggregate level, we find that reported probabilities of default (PDs) and risk-weights are significantly lower for portfolios that were already shifted to the IRB approach compared with SA portfolios still waiting for approval. In stark contrast, however, ex-post default and loss rates go in the opposite direction - actual default rates and loan losses are significantly higher in the IRB pool

\footnotetext{
${ }^{2}$ In the context of lending, it is now well understood that the quality of a loan is not only a function of 'hard' and verifiable information, but also a function of 'subjective' and non-verifiable information. Model-based regulation induces a high weight on 'hard' information and thus provides perverse incentives to manipulate information on dimensions that reduce capital charges (Holmström and Milgrom 1991, Rajan et al. 2012). The inherent complexity of the model-based approach makes it very difficult - if not impossible — for the regulator to detect such behavior.

${ }^{3}$ Banks made an implementation plan that specified the order of implementation several years in advance. They were not allowed to pick individual loans for IRB, but had to shift whole portfolios at the same time. Furthermore, they were not allowed to move IRB portfolios back to SA (see Section 2).
} 
compared with the SA pool. To dig deeper into the mechanism, we examine the interest rate that banks charge on these loans, as interest rates give us an opportunity to assess the perceived riskiness of these loans. ${ }^{4}$ Interest rates in the IRB pool are significantly higher than in the SA pool, suggesting that banks were aware of the inherent riskiness of these loan portfolios, even though reported PDs and risk-weights did not reflect this. Putting it differently, while the PDs/risk-weights do a poor job of predicting defaults and losses, the interest rates seem to do a better job of measuring risk. Moreover, the results are present in every year until the end of the sample period in 2012 and are quite stable across the business cycle. As will be discussed later, during the period of our study the German economy underwent both a downturn and a recovery. Interestingly, the IRB models underpredict defaults across the business cycle.

Clearly, portfolios that were shifted first to the new, model-based approach might differ from portfolios that were shifted later. This non-random assignment of loans within the group of IRB banks raises concerns about the nature of omitted variables and their effect on statistical inference. As discussed in Section 2, banks started with loan portfolios in which they had more expertise and therefore more data for a reliable calibration of the internal model. Thus, the non-random assignment of loans is likely to generate a downward bias on our estimates, as one would expect models that have not yet been certified by the regulator to perform worse. To address this issue we also investigate differential effects on risk estimates for SA and IRB loans to the same firm. This within firm analysis mitigates concerns related to omitted variables (such as macro factors) which may differentially affect SA and IRB loans.

The following example illustrates our empirical strategy: Consider a firm that has two loans, both from IRB banks. For one bank, the loan is in a portfolio that has already been shifted to the new approach (IRB pool), while for the other bank the loan is in a portfolio that is awaiting approval from the regulator (SA pool). While both banks estimate the same variable-the firm's PD within the next year-capital charges depend on the estimated PD for loans in the IRB pool, but not for loans in the SA pool. ${ }^{5}$ Comparing PDs, actual default rates and other contract terms for loans to the same firm but under different regulatory approaches allows us to identify the effects of model-based capital regulation on the variable of interest. Furthermore, we are able to exploit within bank variation in

\footnotetext{
${ }^{4}$ Since firms are not required to report the corresponding interest rates, we obtain effective interest rates from matching the credit register data with detailed income statement data from Bundesbank (see Section 2 and Appendix A for details).

${ }^{5}$ Importantly, PDs are meant to estimate the firm's probability of default. They do not consider other parameters such as recovery rates or losses given default. Thus, both banks are expected to arrive at similar estimates for the PD.
} 
the regulatory approach, which allows us to systematically control for bank specific shocks.

The loan-level analysis yields very similar insights. Even for the same firm in the same year, we find that both the reported PDs and the risk-weights are systematically lower, while the estimation errors (i.e., the difference between a dummy for actual default and the PD) are significantly higher for loans that are subject to the IRB approach vis-à-vis the SA approach. Again, the interest rates charged on IRB loans are higher despite the reported PDs and risk-weights being lower. The results are robust to the inclusion of bank interacted with year fixed effects that control for bank specific shocks.

The incongruence between reported PDs/risk-weights and interest rates suggests that the underperformance of IRB models vis-à-vis SA models was not driven by unanticipated events on the part of the bank. However, it is possible that other differences between IRB and SA portfolios (e.g., differences in the bank's market power) explain our finding. Put differently, market power in a specific portfolio of loans may allow a bank to charge interest rates that are higher than those that would be charged in a competitive market.

To address this issue, we further sharpen the analysis by exploiting the non-linearity in the mapping between PDs and risk-weights. The relationship between PDs and risk-weights is concave; it is very steep for low PDs and gradually flattens for high PDs (see Figure 1). This non-linearity generates differential incentives to misreport PDs. Specifically, a small decrease in the PD induces a reduction in risk-weights that is much larger for low PD loans than it is for high PD loans. In line with this observation, we find that while our results exist across the entire PD band, the effects are much larger for low PD loans for which small reductions in the PD imply large reductions in the risk-weight. Importantly, this specification systematically controls for time varying omitted factors that might explain the selection of loans into the IRB pool within a specific bank. ${ }^{6}$

We also examine how the results vary with the complexity of model-based regulation. There are two versions of the model-based approach, the foundation approach (F-IRB) and the advanced approach (A-IRB). Under the F-IRB approach, banks estimate only the PD while other parameters such as loss given default (LGD) or exposure at default (EAD) are provided by the regulator and hard wired into the risk-weight calculation. Under the A-IRB approach, banks may use their internal models to estimate not only the PD but also the LGD and the EAD. Interestingly, we find that the

\footnotetext{
${ }^{6}$ The specification non-parametrically controls for differences that may exist between SA and IRB models.
} 
breakdown in the relationship between risk-weights and actual loan losses is more severe the more discretion is given to the bank: while the same patterns are present for both F-IRB and A-IRB portfolios, the results are much more pronounced for loans under the A-IRB approach, which is clearly more complex and accords more autonomy to the bank.

The high compliance costs associated with the model-based approach meant that only the larger banks adopted it. These large banks benefited from the new regulation and expanded their lending, potentially at the expense of smaller banks. Specifically, we find that banks that opted for the introduction of the model-based approach experienced a reduction in capital charges and consequently increased their lending by about 9 percent relative to banks that remained under the traditional approach. IRB banks increased their lending to the same firm significantly more than SA banks when the firm's PD (and hence the capital charge) was relatively low, but not when the firm's PD was relatively high. Thus, the reform achieved a tighter link between estimated PDs and a bank's lending decision, but the crucial link between PDs and actual default rates was lost in the process. Thus, this complex, model-based regulation created barriers to entry and subsidized larger banks. This seems rather paradoxical, given the systemic risk associated with larger banks.

All in all, our results suggest that complex, model-based regulation has failed to meet its objective of tying capital charges to actual asset risk. Counter to the stated objective of the reform, aggregate credit risk of financial institutions has increased. Furthermore, as discussed earlier, the IRB banks charged on average higher interest rates on IRB loans compared to SA loans. Thus, even though regulatory capital charges of IRB loan portfolios were reduced, banks were aware of higher credit risk in these portfolios (as reflected in the higher rates).

Our paper connects several strands of the literature. The literature on regulatory complexity is the obvious starting point. Some argue that complex and sophisticated rules are often dominated by simpler regulation that is easier to enforce (Glaeser and Shleifer 2001). Complex regulation imposes a significant enforcement cost on society and provides incentives to regulated entities to find ways around the regulation. ${ }^{7}$ Recent empirical evidence is provided by Becker and Opp (2014), who show that giving insurance companies greater discretion in calculating their capital requirements led to much lower capital levels (see Koijen and Yogo 2014a,b for further evidence on regulation in the insurance sector). We add to this literature by examining how the introduction of model-based

\footnotetext{
${ }^{7}$ As formulated by Kane (1977), complex rules in credit markets are likely to initiate "a dialectical process of adjustments and counteradjustments [in which] bureaucratic controls and market adaptation chase each other round and round, generating additional problems, confrontations, and costs for society at large."
} 
regulation affected credit risk of financial institutions.

A small but growing number of papers analyzes how ratings used for regulatory purposes affect financial stability. As shown by Rajan et al. (2012) in the context of securitization, risk depends on the behavior of the parties involved, it may change over time, and tracking it for regulatory purposes may be near-impossible. ${ }^{8}$ Most recently, the Basel Committee on Banking Supervision (2013) published an extensive study that showed a considerable impact of banks' modeling choices on riskweights, documenting that estimated risk parameters vary widely across banks, even for the same exposures. ${ }^{9}$ As a consequence, market participants seem to lose faith in the meaning of risk-based capital ratios (Demirgüç-Kunt et al. 2013). ${ }^{10}$ Further, Hellwig (2010) argues that model-based capital regulation suffers from the fact that many of the risks involved are not exogenously given, but endogenously determined. Acharya et al. (2014) question the predictive abilities of risk-weights, as they are based on accounting data, can only be updated ex-post, and can easily be gamed by banks (see also Hoenig 2013). Our identification strategy in connection with the richness of our data set allows us to identify the effect of the shift towards model-based regulation on financial stability. To the best of our knowledge, our paper is the first to demonstrate that the introduction of model-based regulation actually increased the credit risk of financial institutions.

Our findings have important policy implications. As a response to the financial crisis in 2007-08, the Basel Committee has drafted a third revision of the regulatory framework for banks (Basel III). This framework continues to rely on model-based regulation, but further increases complexity by introducing — among other measures — capital conservation and countercyclical capital buffers. These new tools have been designed to address substantial weaknesses of the old framework that were identified in the recent crisis. While the measures might make sense individually, our results suggest that further increases in complexity are unlikely to increase financial stability. Although regulators at the national and at the European level are increasing their staff in response to the reform, keeping track with ever-increasing complexity might prove to be difficult. The evidence presented in this paper provides support for the view that simpler and more transparent rules would be more effective in achieving the ultimate goal of financial stability. ${ }^{11}$

\footnotetext{
${ }^{8}$ Another example is given by Acharya (2011), who argues that low risk-weights for residential mortgage-backed securities made investment in this asset class attractive and endogenously turned it into a systemically important asset class. Goel and Thakor (2014) develop a theory of coarse credit ratings to explain how coarse credit ratings are better for incentive compatibility than more precise ratings when involved parties have incentives to manipulate reported information.

${ }^{9}$ See also Le Leslé and Avramova (2012) and Firestone and Rezende (2013).

${ }^{10}$ See also Das and Sy (2012), Hagendorff and Vallascas (2013), and Mariathasan and Merrouche (2014).

${ }^{11}$ See, e.g., Glaeser and Shleifer (2001), Hellwig (2010), Hoenig (2010), Haldane (2011), Haldane (2012), Admati and
} 
The rest of the paper is organized as follows. In the next section we describe the institutional details of the Basel II introduction in Germany, before we introduce our data set in Section 3. We explain our empirical strategy in Section 4 and present our main findings in Section 5. Afterwards we analyze how the reform affected banks' lending decisions in Section 6. Section 7 discusses remaining concerns and Section 8 concludes.

\section{The introduction of model-based regulation in Germany}

One of the main objectives of bank regulation in recent decades has been to establish a closer link between capital charges and actual asset risk. Regulators around the world promoted the adoption of stronger risk management practices by the banking industry in order to achieve the ultimate goal of a sound and stable international banking system. ${ }^{12}$ In 1988, the Basel I agreement introduced risk-based capital charges by assigning bank assets into different risk groups (or buckets) with preassigned risk-weights (Basel Committee on Banking Supervision 1988). Risk-weighted assets were calculated by multiplying these risk-weights $(0,10,20,50$, or 100 percent) with actual asset values, and capital requirements were defined in terms of risk-weighted assets.

The next revision of this regulatory framework-Basel II, which was introduced in 2007allowed banks to choose between two broad methodologies for calculating capital charges for credit risk: The so-called standard approach (SA) which was basically equivalent to the old Basel I framework with fixed risk-weights for corporate loans (100 percent of the loan amount) ${ }^{13}$ and the internal ratings-based (IRB) approach — with an additional distinction between Foundation IRB (F-IRB) and Advanced IRB (A-IRB) — that tried to establish a more granular link between capital charges and individual asset risk. Under IRB, loans get assigned individual risk-weights that crucially depend on the bank's internal risk estimates. Risk-weighted assets are calculated by multiplying these riskweights with actual assets values, and capital requirements are defined in terms of risk-weighted assets as under Basel I (Basel Committee on Banking Supervision 2006).

Hellwig (2013), Haldane (2013), Hoenig (2013), and Acharya et al. (2014).

${ }^{12}$ The introduction of risk-weighted capital charges and the potential problems related to them have been discussed in several papers, e.g. Brinkmann and Horvitz (1995), Jones (2000), Daníelsson et al. (2001), Kashyap and Stein (2004), Hellwig (2010), Brun et al. (2013), and Behn et al. (2014). For an assessment from the side of the regulator see Basel Committee on Banking Supervision (1999).

${ }^{13}$ Risk mitigation instruments (i.e., collateral and guarantees that are eligible according to Basel II) can be used to decrease capital requirements. Exceptions to the fixed risk-weights are cases where borrowers have external credit ratings, as the SA allows banks to use these ratings to determine capital requirements. However, the German market for corporate bonds is very small; hence, very few companies have an external rating. 
Under both versions of the model-based approach, the F-IRB and the A-IRB, the firm-specific probability of default (PD) — our main variable of interest—has to be estimated by the bank. Therefore, we do not distinguish between the two approaches in large parts of the empirical analysis (we investigate differences between F-IRB and A-IRB in Section 5.4). Under the F-IRB approach, the bank estimates only the firm-specific PD, while loan-specific loss given default (LGD), exposure at default (EAD), and maturity are given by the regulator and hard-wired into the calculation of riskweights. Under the A-IRB approach-which may be chosen by the most sophisticated banks-banks plug calculated effective maturities and their own estimates for LGD and EAD (instead of the F-IRB standard values) into the formula and obtain similar mappings between PDs and regulatory riskweights. The mapping between banks' internal risk estimates and regulatory risk-weights (using the standard parameters of the F-IRB approach) is illustrated in Figure 1. The risk-weight curve is relatively steep for the lowest PDs and becomes flatter for higher PDs. To provide banks with incentives to introduce IRB, it was calibrated in a way that ensured that capital requirements should be lower under IRB than under SA (Basel Committee on Banking Supervision 2006, p. 12).

PD models used for regulatory purposes are meant to estimate borrowers' one-year probability of default. ${ }^{14}$ Although models are estimated on a portfolio basis, PDs should be portfolio invariant in the sense that the capital required for a given loan depends only on the risk of that loan and not on the portfolio it is added to (Basel Committee on Banking Supervision 2005). ${ }^{15}$ For corporate loans, the most important determinant of the PD is accounting information from firms' financial statements (see, e.g., Krahnen and Weber 2001). For loans to small and medium enterprises (SMEs), where there is often a significant publication lag for accounting information, target financial ratios or industry characteristics may also be used. Besides these quantitative factors, qualitative information such as a firm's management quality or its competitive situation can also be included in the models. However, since such information is by definition hard to quantify its impact on the risk estimate is rather limited. A prominent PD model used for the estimation of corporate credit risk is Moody's RiskCalc $^{T M}$ model (Moody's Analytics 2013). To obtain predicted probabilities of default for a given portfolio, historical information on corporate defaults is regressed on accounting information such

\footnotetext{
${ }^{14}$ According to the regulation, a creditor is in default if (a) the bank has valid indications that the creditor will not be able to fulfill his obligations, or (b) the creditor is more than 90 days past due on his obligations (Solvabilitätsverordnung 2006).

${ }^{15}$ As noted in the BIS document, "taking into account the actual portfolio composition when determining capital for each loan [...] would have been a too complex task for most banks and supervisors alike, [as] diversification effects would depend on how well a new loan fits into an existing portfolio. As a result, the 'Revised Framework' was calibrated to well diversified banks" (Basel Committee on Banking Supervision 2005, p.4).
} 
as the equity ratio, capital structure, net debt ratio, sales growth, net profit ratio, personnel cost ratio, payables payment period, or cash flow per liabilities. In a second step, estimates from this model are used to attribute predicted PDs to current and new borrowers. The borrower-specific PD estimates from banks' internal models have to be updated at least once a year to incorporate new information that becomes available. In cases where loan officers consider model outputs to be unreasonable they have the option of overwriting the predicted PD. However, if such overwrites occur too frequently, the regulator may ask the bank to revise its model.

While the Basel framework was meant to harmonize international bank regulation, the implementation process of the new framework differed between countries. In Germany, Basel II was implemented by revision of the Solvabilitätsverordnung (2006), which provides the foundation for national bank regulation. The law specifies a strong supervisory review that includes on-site audits to ensure compliance with the regulatory framework (see also Bundesbank 2004). Banks have to validate their models on an annual basis and adjust them if their estimates are inconsistent with realized default rates (see also Bundesbank 2003). Further, risk models have to be certified by the supervisor and banks have to prove that a specific model has been used for internal risk management and credit decisions for at least three years before it can be used for regulatory purposes. Since the introduction of the IRB approach imposes sizeable organizational efforts and administrative expenses and also requires a certain degree of sophistication (Basel Committee on Banking Supervision 2004), it was only implemented by the largest banks. ${ }^{16}$ Of our sample of 1,603 German banks, only 45 banks applied for an IRB license, but these banks account for about 50 percent of the loans in our sample. Of the 45 banks that introduced the IRB approach, 17 introduced F-IRB, 18 introduced A-IRB, and 10 use F-IRB for some portfolios and A-IRB for other portfolios.

The banks that opted for model-based regulation did not apply the new approach to all loans at once, but agreed on a gradual implementation plan with the supervisor. The plan specified an order according to which different loan portfolios were shifted to IRB. As the calibration of a meaningful PD model requires a sufficient amount of data on past loan performance, banks typically started with loan portfolios in business units where they were relatively active. Other portfolios remained under SA until banks were able to prove that the respective model had been used internally for at least three years and did not over- or underpredict defaults. Otherwise, regulators delayed the approval of the

\footnotetext{
${ }^{16}$ To be eligible for the model-based approach to capital regulation, banks need to prove that "their rating and risk estimation systems and processes provide for a meaningful assessment of borrower and transaction characteristics; a meaningful differentiation of risk; and reasonably accurate and consistent quantitative estimates of risk" (Basel Committee on Banking Supervision 2006).
} 
model until they felt comfortable about the reliability of the model. The phased roll-out of IRB meant that during the transition, which typically lasted for several years, banks had both IRB and SA loans in their portfolios. We exploit this feature of the implementation process in our empirical section, where we compare PD estimations with actual default rates for loans that are subject to different regulatory approaches.

\section{Data}

Our principal source of data is the German credit register compiled by Deutsche Bundesbank. As part of its supervisory role, the central bank collects data each quarter on all outstanding loans of at least $€ 1.5$ million. ${ }^{17}$ The data set starts in 1993 and includes information on the lender's and the borrower's identity, the amount of the loan outstanding and several other loan characteristics. In response to the Basel II reform, reporting requirements for the credit register have been expanded considerably from 2008 onwards. In addition to the previous information, banks now also report loan-level information on the regulatory approach (SA or IRB) and the estimated probability of default (PD). Moreover, the database contains information on risk-weighted assets and actual loan losses. For the empirical analysis, we combine this loan-level data with annual bank balance sheet information from Bundesbank's BAKIS database and annual firm balance sheet information from Bundesbank's USTAN database.

Our sample includes 1,603 German banks, 45 of which opted for IRB following the introduction of Basel II (we will refer to these 45 banks as 'IRB banks'). Panel A of Table 1 shows that the average IRB bank is larger and less capitalized than the average SA bank, whereas average ROA is similar in the two groups of banks. As mentioned before, only large and internationally active banks introduced IRB, while smaller regional banks remained under the standard approach.

Our loan-level data set contains three types of loans: (1) loans provided by SA banks; (2) loans provided by IRB banks that are still subject to SA; and (3) loans provided by IRB banks that are already subject to the new approach. ${ }^{18}$ In large parts of the empirical analysis, we use only loans provided by IRB banks. As IRB banks aim to transfer all eligible loan portfolios to the new approach

\footnotetext{
${ }^{17}$ Since we focus on corporate lending, this cut-off does not constitute a big issue for our analysis. The amount of the average loan in our sample is $€ 23$ million and hence well above the cut-off, which makes it unlikely that we miss out on many loans.

${ }^{18}$ In Section 5.4, we break these loans down into those under Foundation IRB (F-IRB) and those under Advanced IRB (A-IRB).
} 
once the respective model is certified by the regulator, they report PDs for both IRB loans and SA loans. We use PDs for SA loans as a benchmark against which we evaluate the performance of PDs for IRB loans. Descriptive statistics for SA and IRB loans provided by IRB banks during our sample period from 2008 to 2012 are presented in Panel B of Table 1, where loans are classified according to the regulatory approach under which they were issued. ${ }^{19}$ Although information in the credit register is available on a quarterly basis, PDs are updated only once a year unless there is some dramatic event or adverse news. Thus, to be conservative and avoid the duplication of observations, we include only one quarter per year in large parts of the empirical analysis. Specifically, we restrict ourselves to the fourth quarter of each year, as most German companies report their earnings in the second or third quarter of the year and this information is typically used by the bank to update the PD. ${ }^{20}$

The first line of the table shows that the average PD is higher for SA loans (2.6 percent) compared with IRB loans (1.8 percent). While the PD estimates the firm-specific probability of default, the risk-weight for a specific loan also incorporates loan-specific information (e.g., the collateralization of the loan). For SA loans, the corresponding risk-weight does not depend on the PD and is equal to 100 percent of the unsecured fraction of the loan amount. ${ }^{21}$ Overall, this translates into an average risk-weight of 61.6 percent for SA loans, which is considerably higher than the average risk-weight for IRB loans (49.0 percent). Furthermore, banks are required to report actual losses for loans in default to the credit register. ${ }^{22}$ Since certain loans are backed by collateral or guarantees, the consequences of a borrower's default may vary. For both SA loans and IRB loans, the actual loan loss rate is around 0.5 percent. Since the German credit register does not contain direct information on interest rates, we back out effective interest rates as described in detail in the Appendix A. Specifically, the simple structure of most German loan contracts allows us to infer the repayment schedules from the quarterly data on loan amounts. We match this contract-level information with firm-level data on aggregate interest payments obtained from Bundesbank's USTAN database and back out effective annual interest rates on the loan contract level. ${ }^{23}$ As shown in the table, interest

\footnotetext{
${ }^{19}$ Specifically, new lending relationships are classified according to the regulatory approach used at issuance. Existing relationships may be re-classified whenever there is a large increase in the loan amount. All of a bank's loans to a specific firm have to be classified under the same approach (i.e., SA or IRB), so that there is no variation in the regulatory approach within the same bank-firm relationship at any point in time.

${ }^{20}$ Results for the remaining quarters are very similar to the results we report.

${ }^{21}$ The Basel regulations include a discount for loans to small and medium enterprises (SMEs) as the regulator wants to promote lending to these firms. Specifically, under Basel II, loans to firms with a turnover of $€ 50$ million or less are subject to lower capital charges, as regular risk-weights are multiplied with a correction factor depending on the exact amount of the turnover.

${ }^{22}$ The reporting rules for actual loan losses are according to the German Commercial Code.

${ }^{23}$ As we have to match the data from the credit register with firm balance sheet information for this procedure, the sample size for interest rates is considerably lower than for the remaining variables. We are able to back out interest rates
} 
rates for loans under the standard approach are on average slightly lower (7.7 percent) than interest rates for loans under IRB (8.9 percent). The last line of Panel B shows the average change in the amount of loans outstanding around the introduction of Basel II. ${ }^{24}$ The average IRB loan in our sample was increased by about 6.4 percent over the Basel II introduction, while the average SA loan was increased by about 1.6 percent.

Finally, Panel C of Table 1 contains descriptives for firm-level variables. Several accounting variables are obtained by a hand-match of the Bundesbank USTAN database with the credit register. $^{25}$ The match was conducted based on company name, location, and industry segment, which are available in both data sources. The matched dataset contains detailed information on lending relationships and balance sheet items for 5,961 distinct firms. We report summary statistics on total assets, debt to assets and return on assets (ROA) for this sample. The average size of our sample firms is 154 million euros, the average debt to asset ratio is 34.3 percent, and the average return on assets is 7.9 percent.

\section{Empirical strategy}

As discussed earlier, the introduction of Basel II was staggered over time, allowing us to exploit within bank variation in the regulatory approach. Restricting ourselves to the sample of loans from IRB banks, we estimate loan-level equations of the following type:

$$
y_{i j t}=\alpha+\delta \cdot \mathbb{1}_{j p t}+\varepsilon_{i j t},
$$

where $i$ denotes the individual bank, $j$ denotes the individual firm, $p$ denotes the loan pool within the bank (IRB or SA), and $t$ denotes time. The dependent variable $y_{i j t}$ is the logarithm of the loanspecific PD reported at time $t$ by the bank to the supervisor (LOG(PD)); alternatively, we use the ESTIMATION ERROR (i.e., the difference between a dummy for ACTUAL DEFAULT and the PD), the ratio of RWA TO LOAN (i.e., the ratio of a loan's risk-weighted assets by the corresponsing loan amount), the actual LOSS RATE, or the INTEREST RATE as a dependent variable. The dummy

for 11,811 loan-year observations. For a small sample we can compare the interest rates we have backed out with the actual interest rates and find that these match very closely.

${ }^{24}$ The sample includes all loans in the credit register that have an observation both before and after the reform. We calculate the change in lending around the reform by collapsing all quarterly data for a given exposure into single pre-event and post-event periods by taking the average of the two years before and the two years after the Basel II introduction. The change in lending is defined as the difference in the logarithm of these averages, so that there is one observation per loan.

${ }^{25}$ Even though the credit register and the accounting information all come from Deutsche Bundesbank, the two datasets have no unique identifier. For a detailed description of the USTAN database see Bachmann and Bayer (2014). 
$\mathbb{1}_{j p t}$ takes on a value of 1 when the respective loan belongs to the IRB pool of bank $j$ at time $t$ and 0 otherwise. Furthermore, the equation includes a constant $\alpha$ and a random error term $\varepsilon_{i j t}$. In order to allow for potential correlation among default events for loans from the same bank or in the same year, standard errors are double clustered at the bank and year level in all regressions. ${ }^{26}$

Interpreting $\delta$ as the causal impact of the regulatory approach on $y_{i j t}$ requires that the covariance between $\mathbb{1}_{j p t}$ and $\varepsilon_{i j t}$ is equal to 0 , i.e., $\operatorname{Cov}\left(\mathbb{1}_{j p t}, \varepsilon_{i j t}\right)=0$. Clearly, loans that were shifted first to the model-based approach are potentially different from loans that remained under the traditional approach and were shifted later. This non-random assignment of loans to IRB and SA pools raises endogeneity concerns so that our coefficients could potentially be biased. To address this issue, we focus on firms that borrow from at least two banks at the same time, one bank where loans to the firm belong to a portfolio that has already been shifted to IRB and one bank where they are still under SA. Using this sample of firms, we estimate:

$$
y_{i j t}=\alpha_{i t}+\alpha_{j t}+\delta \cdot \mathbb{1}_{j p t}+\varepsilon_{i j t},
$$

where $\alpha_{i t}$ and $\alpha_{j t}$ denote firm $\times$ year and bank $\times$ year interactions, respectively, and the remaining variables are defined as in Equation (1). By adding $\alpha_{i t}$ we are able to systematically control for timevarying heterogeneity across firms. That is, we can check whether the PD reported by different banks for the same firm in the same year is lower if a loan is part of the IRB pool as compared with the SA pool. A similar analysis can be done for the other dependent variables (i.e., ESTIMATION ERROR, RWA TO LOAN, LOSS RATE, and INTEREST RATE). Further, the inclusion of $\alpha_{j t}$ allows us to control for time-varying heterogeneity across banks; i.e., we can rule out that differences between banks are driving our results. Our identification strategy is illustrated in Figure 2.

While the identification strategy described above controls for bank specific shocks $\left(\alpha_{j t}\right)$, it is unable to control for time varying omitted factors that might influence the selection of loans into the IRB pool within a bank. For example, it could be that banks have a higher market power (potentially varying over time) for loans in portfolios that have already been shifted to the IRB approach. To control for such effects, one would have to include bank $\times$ IRB $\times$ year interactions, $\alpha_{j p t}$, which would absorb the variable of interest, $\mathbb{1}_{j p t}$. To circumvent this issue, we exploit the non-linear shape of the risk-weight formula to further corroborate our results. Incentives to underreport borrowers' PD are particularly pronounced for firms with relatively low PDs, as the shape of the risk-weight

\footnotetext{
${ }^{26}$ Double clustering at the bank and year level gives the most conservative standard errors. We also tried double clustering at the bank and firm level, and the firm and year level.
} 
curve implies that small increases in the PD lead to large increases in capital charges for loans to these firms (see Figure 1). We can directly test these assertions by estimating the following equation:

$$
y_{i j t}=\alpha_{i t}+\alpha_{j p t}+\delta \cdot\left[\mathbb{1}_{j p t} \times p d_{i}\right]+\varepsilon_{i j t}
$$

where $\alpha_{j p t}$ denote bank $\times$ IRB $\times$ year interactions (i.e., fixed effects for the SA and IRB pool of bank $j$ at time $t$ ) that allow us to systematically control for any observable and unobservable differences between the SA pool and the IRB pool of a specific bank. Further, $p d_{i}$ is the average PD for loans to firm $i$ at the time of loan origination, and the remaining variables are defined as above. When using LOG(PD) as the dependent variable, we expect $\delta$ to be positive, which would mean that the underreporting of PDs for IRB loans compared with SA loans to the same firm is more pronounced for low PD firms. When using the ESTIMATION ERROR as the dependent variable, we expect $\delta$ to be negative, which would mean that the relative underestimation of actual default rates is larger for firms that score well on the risk model. Importantly, the inclusion of bank $\times$ IRB $\times$ year interactions allows us to control for any time varying omitted factors that could potentially influence the selection of loans into the IRB pool within a specific bank.

\section{Empirical results}

\subsection{Aggregate analysis}

Table 2 and Figure 3 show average values of key variables between 2008 and 2012 for SA and IRB loans from the 45 banks that adopted the IRB approach (IRB banks). There are 66,045 lending relationships in 2008, 14,713 under SA and 51,332 under IRB. Additional portfolios are shifted to IRB throughout our sample period, which is why the number of SA loans declines to 8,907 in 2012.

We start by assessing how PD estimates from banks' internal risk models compare with actual default rates for loans under SA and IRB. As explained in Section 2, PDs are meant to estimate oneyear default rates. The dummy variable ACTUAL DEFAULT captures whether a loan is in default in at least one of the four quarters following the one in which the PD is evaluated. Importantly, all loans that are already in default in a respective quarter are excluded from the analysis.

We find that average PDs for IRB loans are always lower than average PDs for SA loans. As shown at the bottom of Table 2, the difference between the two groups lies between 0.7 and 
1.1 percentage points and is highly significant. Kernel density plots for PDs further illustrate this point (see Figure 4). Clearly, the distribution for IRB loans is to the left of the distribution for SA loans in all years. This is confirmed in a Kolmogorov-Smirnov test for equality of distributions: The hypothesis that the distributions for SA loans and IRB loans are equal can be rejected at the 1 percent level in all cases.

In sharp contrast, actual default rates for IRB loans are higher than those for SA loans in all years. They fluctuate between 1.9 and 2.6 percent for SA loans, and between 2.1 and 3.0 percent for IRB loans. For each of our five sample years, model-based PDs for IRB loans are lower than actual default rates. For SA loans, we observe a close match of PDs and default rates in the first year and a slight overprediction of default rates in the remaining years. During our sample period, the German economy underwent a slowdown and a recovery. As documented in Figure 5, GDP decreased and aggregate default rates increased until the first quarter of 2009. For the rest of our sample period GDP recovered and the default rate constantly decreased. While these business cycle fluctuations affected the level of default rates, the difference in performance between IRB models and SA models is relatively stable over the business cycle. ${ }^{27}$

Although startling in themselves, the results for PDs and actual default rates do not necessarily mean that aggregate credit risk is higher for loans under IRB. Apart from the PD, risk-weights in the model-based approach also depend on loan-specific factors such as the loss given default (LGD), exposure at default (EAD), and the maturity (M) of the loan. An assessment of the reform's impact on overall credit risk and bank stability needs to take all loan-specific factors into account.

The data from the credit register allows us to examine this issue. Apart from information on the PD, it also contains exposure-level information on risk-weighted assets and actual loan losses. The risk-weight includes all firm-specific as well as loan-specific information relevant for a loan's regulatory capital charge. Loan losses capture the actual amount the bank has to write off in case of default of a specific loan (see Section 3). Comparing regulatory risk-weights to actual losses for loans under SA and loans under IRB allows us to evaluate the reform's overall impact on credit risk.

Average values for the ratio of RWA TO LOAN and the actual LOSS RATE are also displayed in Table 2 and Figure 3. Risk-weights for IRB loans are about 10 to 15 percent lower than riskweights for SA loans, which means that banks have to hold much less capital for IRB exposures. At

\footnotetext{
${ }^{27}$ The difference in estimation error (actual defaults - PD) between the IRB and SA loan pool is 1.6 percentage points (PP) in 2008; 1.4 PP in 2009; 1.2 PP in 2010; 1.3 PP in 2011, and 1.0 PP in 2012.
} 
the same time, actual loss rates are similar among both groups; if anything, they tend to be slightly higher for loans under IRB in most years. Although banks have lower capital charges on average, they actually tend to lose more money with loans under IRB.

Taken together, findings on PDs, actual defaults, risk-weights and loss rates suggest that credit risk has increased under model-based regulation. But do these findings mean that banks misjudged credit risk under the new approach? Or were they aware of the higher credit risk in portfolios under the model-based approach, and did they simply used the new regulation to economize on regulatory capital? Average interest rates provide evidence in favor of the latter explanation. As shown in Table 2 and Figure 3, and in stark contrast to PD and risk-weight estimates, interest rates for loans under IRB are higher than interest rates for loans under SA. This suggests that banks were aware of the actual risk involved with loans under the model-based approach. We will now test our assertions more formally in a regression framework.

\subsection{Regression framework: IRB versus $S A$ loans}

Regression results using the logarithm of the loan-specific PD as a dependent variable are presented in Table 3. Column 1 shows that PDs for IRB loans are considerably lower than PDs for SA loans. We include firm fixed effects in column 2 and show that banks assign significantly lower PDs to the same borrower if the loan is part of an IRB portfolio as compared with an SA portfolio. As already noted, PDs do not capture recovery rates that might also vary from bank to bank. Thus, all banks that are providing loans to a specific firm should arrive at similar PD estimates, even though they may have very different financial contracts with the firm. ${ }^{28}$ This result is robust to the inclusion of year fixed effects in column 3 . In column 4 , we include firm $\times$ year interactions. In this test, the sample is constrained to firm-year observations where the respective firm has at least one IRB loan and at least one SA loan from an IRB bank. The negative coefficient implies that PDs for IRB loans are significantly lower than PDs for SA loans to the same firm in the same year. Finally, the result is also robust to the inclusion of bank $\times$ year interactions in column 5: PDs from the same bank in the same year are significantly lower for loans under IRB. The magnitudes are large: PDs for IRB loans are 22 to 45 percent smaller than PDs for SA loans. ${ }^{29}$ These findings strongly suggest that the introduction of model-based regulation had a direct impact on banks' ability to evaluate credit risk. Under the

\footnotetext{
${ }^{28}$ For example, a bank giving a secured loan to a firm and another bank giving an unsecured loan to the same firm should arrive at similar PDs even though exposures at default and recovery rates are likely to be different.

${ }^{29}$ The effect is equal to $\exp (\delta)-1$ (Halvorsen and Palmquist 1980).
} 
new regulation, banks have incentives to understate PDs, which is illustrated by lower PDs assigned to the same firm in the same year.

In Table 4 we use the loan-specific ESTIMATION ERROR, defined as the difference between the ACTUAL DEFAULT dummy and the PD, as a dependent variable. Column 1 shows that PDs for IRB loans underestimate actual default rates by about 0.8 percent on average, whereas the estimation error for SA loans is not significantly different from 0 . As expected, the difference between the two groups of loans is significant in specifications that include firm fixed effects (column 2), year fixed effects (column 3), firm $\times$ year interactions (column 4), and bank $\times$ year interactions (column 5). Compared with SA loans, PDs for IRB loans underestimate actual default rates by 0.5 to 1.3 percentage points.

Next, we look again at risk-weights and actual loan losses. Applying the same estimation strategy as before, we find that the ratio of RWA TO LOAN is 10 to 15 percent lower for loans under IRB, even for loans to the same firm in the same year (Table 5). However, as already documented in the previous section, actual loan losses are similar in the two groups of loans. If anything, they are higher for loans under IRB, which is indicated by the significantly positive coefficients for D(IRB LOAN) in columns 2-4 of Table 6.

Finally, interest rates for these loans are about 0.9 percent higher than interest rates for loans under SA (Table 7, column 1). Also, in the remainder of the table, we get highly significant coefficients for the IRB loan dummy, which is a remarkable finding. In sharp contrast to PDs and RWA TO LOAN, interest rates on IRB loans are significantly higher than interest rates on SA loans to the same firm in the same year. It is important to note that we only have interest rates on a small subset of loans which explains the drop in the number of observations. ${ }^{30}$

\subsection{Exploiting the non-linearity of the Basel function}

In this section we present a sharper test to address potential selection concerns arising from the order in which IRB banks shifted their loan portfolios from SA to IRB. As discussed in detail in Section 2, the selection of IRB portfolios was based on data quality and experience of the bank, and should therefore result —if at all—in a downward bias of our coefficients. Nevertheless, to address any

\footnotetext{
${ }^{30}$ We have re-estimated all specifications on the subset of loans for which we have the interest rates and the patterns we find are very similar to those seen in the full sample.
} 
remaining concerns, we saturate Equation (2) with bank $\times$ IRB $\times$ year interactions and exploit the non-linear shape of the mapping from PDs into regulatory risk-weights (recall Figure 1). Specifically, we evaluate credit risk models for IRB loans relative to those for SA loans, distinguishing between firms with relatively low PDs and firms with relatively high PDs. The shape of the risk-weight function implies that incentives to underreport PDs are higher for loans to the former group of firms. ${ }^{31}$

Table 8 provides regression results for Equation (3). We first use the PD as a dependent variable and estimate the difference in PDs between loans under SA and IRB, distinguishing between firms with an average initial PD below and above the median. We either use the whole sample of firms (columns 1 and 2), or the restricted sample of firms that have both IRB and SA loans from IRB banks (columns 5 and 6). Strikingly, PDs for loans under IRB are lower than PDs for loans under SA, particularly for firms with below median PDs. This means that banks report lower PDs for precisely those loans where small reductions in the PD translate into large reductions in risk-weighted assets. In columns 3 and 7 we interact the firm's average PD with the IRB loan dummy and find a significant effect for the interaction term. The magnitude of the coefficient implies that underreporting of PDs for loans under the model-based approach as compared with loans under the traditional approach is about 14.5 percent larger for firms at the $25^{\text {th }}$ percentile compared with firms at the $75^{\text {th }}$ percentile of FIRM PD (column 3). Including firm fixed effects and restricting the sample to firms with multiple relationships under IRB and SA, the magnitude is about 6.8 percent (column 7). Finally, we add bank $\times$ IRB $\times$ year interactions that control for any differences between SA and IRB portfolios of a specific bank (columns 4 and 8). Results are unaffected.

In Table 9, we estimate Equation (3), using the ESTIMATION ERROR as a dependent variable. There are considerable differences in the ESTIMATION ERROR between IRB and SA loans for firms with below median average PDs (columns 1 and 5). Within this sample, the underestimation effect is about 1 percentage point larger for loans under IRB, a significant effect given the sample median of 0.9 percent for the average PD. For firms with above median average PDs, i.e., firms in the flat section of the PD-to-risk-weight-mapping, there is no statistically significant difference between loans under the new and old regulatory regimes. Interaction terms are highly significant and economically meaningful: The difference in ESTIMATION ERROR between IRB and SA loans is 0.3 to 0.5 percentage points larger for firms at $25^{\text {th }}$ percentile as compared with firms at the $75^{\text {th }}$

\footnotetext{
${ }^{31}$ This can be illustrated with a simple example: Assume that a firm has a PD of 1 percent; applying standard parameters for $\mathrm{LGD}, \mathrm{EaD}$, and M, reducing the firm's PD by 0.5 percentage points (PP) reduces risk-weighted assets by about $30 \mathrm{PP}$. In contrast, for a firm with a PD of 3 percent, a reduction by 0.5 PP reduces risk-weighted assets by 8 PP.
} 
percentile of FIRM PD (column 3 and 7). As above, the inclusion of bank $\times$ IRB dummy $\times$ year interactions does not affect the results (columns 4 and 8).

Results in this section suggest that our findings are driven by incentives to underreport PDs in order to economize on regulatory capital, as the underestimation effect is stronger for those loans where small decreases in the PD imply large decreases in the risk-weight. The inclusion of bank $\times$ IRB $\times$ year interactions non-parametrically controls for time varying omitted factors, such as market power, which could be related to the selection into the IRB pool within a bank. Furthermore, as the test compares the differential performance of IRB models along the PD band (high PD vs. low PD) with that of SA models along the same band, it obliterates concerns regarding any potential difference between SA and IRB models that could bias the analysis.

\subsection{Foundation versus advanced IRB approach}

We next examine how our findings vary with the complexity of the model-based approach. Banks that opted for the new regulatory approach could choose between two alternatives to determine capital charges for their loan portfolios: The Foundation IRB (F-IRB) approach and the Advanced IRB (A-IRB) approach. The A-IRB approach is considerably more complex compared to the F-IRB approach as the bank estimates not only the borrower's PD, but also loan-specific factors, such as loss given default (LGD) and exposure at default (EAD). Under the F-IRB approach these loanspecific parameters are provided by the regulator and hard-wired into the calculation of risk-weights. Consequently, the discretion in determining capital charges for a given loan exposure is considerably larger under the A-IRB approach.

Table 10 and Figure 6 show average values of estimated PDs, actual defaults, risk-weights, loan losses and interest rates for loans under the F-IRB and the A-IRB approach between 2008 and 2012. Reported PDs (as well as actual defaults) are higher for loans under the A-IRB approach. This pattern is not reflected in the corresponding risk-weights that determine capital charges for these loans. Except for the year 2009, the estimated risk-weights are lower for the loans under A-IRB compared to F-IRB. As shown at the bottom of Table 10 these differences are statistically significant. Thus, on average, estimated LGDs and EADs for loans under the A-IRB approach have to be considerably smaller than the standard parameters used in the F-IRB approach. We compare the actual loan loss rate of loans under the two different model-based approaches to examine whether these low estimates 
on LGD and EAD are justified ex-post. In each of our sample years, the LOSS RATE is considerably higher for loans in the advanced approach. This finding suggests that the overall level of banks' credit risk increases with the discretion given to them in applying complex, model-based regulation. Higher flexibility and higher complexity allow banks to reduce capital charges by influencing various parameters, so that higher actual losses are backed by less regulatory capital. Finally, interest rates charged on A-IRB loans are higher, although the reported risk-weights are lower than those for loans under F-IRB. This suggests that banks are aware of higher risks associated with these loans.

\section{Model-based regulation and lending}

In a final step, we try to identify potential winners and losers of the reform. While large banks had the ability to spread the compliance costs associated with the implementation of the model-based approach over a large portfolio of loans, small banks did not introduce the new regulation. Thus, banks that introduced IRB experienced a significant reduction in capital requirements for loans-both in absolute terms and relative to SA banks that did not introduce the new approach. In this section, we analyze whether the reform's differential impact on capital requirements had consequences for banks' lending behavior.

We have previously documented significantly lower PDs as well as lower average risk-weights for loan portfolios under IRB. Figure 7 shows that, following the reform, banks that introduced the model-based approach expanded their lending to corporate borrowers in Germany. ${ }^{32}$ Prior to the reform, the development of aggregate loans was relatively similar for the two groups of banks. Following the reform, however, we see a sharp increase in aggregate loans for IRB banks, while the loans of SA banks remain relatively constant or even decline. To formalize the analysis, we collapse quarterly bank-level loans into single pre-event and post-event time periods by taking the average of the two years before and the two years after the reform, and regress the change in this variable on a dummy that indicates whether the bank has introduced the model-based approach. Table 11, column 1, shows that IRB banks increased their lending by about 9 percent as compared with SA banks (see Brun et al. 2013 for similar evidence). In column 2 we add several bank-level control variables (i.e., the pre-event logarithm of assets, ratio of equity to assets, ROA and bank ownership dummies) and find that the coefficient for the IRB bank dummy remains significantly positive. To

\footnotetext{
${ }^{32}$ For each group of banks - SA banks and IRB banks-we sum all loans in a given quarter to obtain aggregate loans. The figure shows the logarithm of aggregate loans—scaled by its value in 2007Q1—for SA and IRB banks.
} 
sum up, larger banks drastically expanded their lending relative to smaller banks, resulting in a concentration of market shares in the market for corporate loans.

Under IRB, the capital charge for a specific loan depends on the estimated PD for that loan. Hence, we expect that IRB banks increase lending particularly to those firms where PDs are relatively low. To test this assertion, we collapse the quarterly loan-level data into single pre-event and postevent time periods by taking the averages of the two years before and the two years after the reform, and regress the change in this variable on an interaction between an IRB bank dummy and the firm's PD. Formally, we run the following regression:

$$
\Delta \log (\text { loans })_{i j}=\alpha_{i}+\alpha_{j}+\gamma \cdot\left[\mathbb{1}_{I R B_{j}} \times p d_{i}\right]+\varepsilon_{i j}
$$

where $i$ denotes the individual firm, and $j$ denotes the individual bank. We use the average PD banks report for each firm in 2008Q1, the first quarter for which this information is available. The variable is interacted with the dummy that indicates whether the bank adopted IRB during our sample period. Firm and bank fixed effects are denoted by $\alpha_{i}$ and $\alpha_{j}$, respectively. We cluster standard errors at the bank and firm level in all loan-level regressions. As we are trying to identify a supply side effect, it is important to control for a firm's demand for credit by including firm fixed effects (see Khwaja and Mian 2008). The 44,784 observations in the loan-level regressions correspond to all loans to firms with at least one loan from an IRB bank and at least one loan from an SA bank. Bank fixed effects systematically control for heterogeneity across banks. That is, we test whether the same bank increases its lending relatively more to firms with low PDs, and whether this effect depends on whether the bank is an IRB bank or not.

Estimation results for Equation (4) are presented in Table 11, columns 3 to 6. We interact the IRB bank dummy with the firm PD variable and find that IRB banks increase lending to the same firm relatively more, but less so when the firm's PD is higher (column 3). This effect is robust to the inclusion of firm fixed effects in column 4, bank fixed effects in column 5, and both firm and bank fixed effects in column 6. Economically, the coefficients indicate that an increase of one standard deviation in FIRM PD induces a 1.2 to 2.5 percent smaller increase in loans from IRB banks. In line with our assertion, we find that IRB banks increase lending to the same firm significantly more than SA banks when the firm's PD is relatively low, but not when the firm's PD is relatively high. Overall, we document that the reform did indeed change the quantity and the composition of bank lending. While the reform achieved a tighter link between estimated PDs and a bank's lending decision, the 
crucial link between PDs and actual default rates was lost in the process.

\section{Discussion}

The broad array of results suggests that the introduction of Basel II-type model-based capital regulation affected the validity of banks' internal risk estimates and increased the credit risk of financial institutions. Our findings can be explained by incentives for banks to underreport PDs in order to economize on regulatory capital. In this section, we discuss some remaining concerns and alternative stories that may seem consistent with our findings.

\subsection{Conservatism of SA models}

Our empirical analysis benchmarks the performance of IRB models with SA models. This raises a natural concern: what if the benchmark is incorrect? In other words, if banks take a more conservative approach when estimating PDs for SA loans in order to get these models approved by the regulator, then this would obfuscate the identification strategy. There are several reasons why we do not consider this a cause for concern. To begin with, it should be noted that prior to regulatory approval, banks need to prove that a specific model has been used internally for at least three years and does not under- or overpredict actual default rates (see Section 2). ${ }^{33}$ Thus, strategic conservatism does not really help their cause and only delays the transfer process. Our empirical analysis confirms this view, as we do not find any evidence of strategic behavior. As reported earlier, the coefficient for the SA loan dummy in column 1 of Table 4 is not different from zero. But more importantly, the curvature tests in Section 5.3 directly address any concerns that relate to potential differences between SA and IRB models, as they allow for the inclusion of bank $\times$ IRB $\times$ year interactions that systematically account for such effects. If conservative estimates on SA loans were driving our results, one would not expect the underestimation effect to be stronger for low PD loans.

\subsection{Regulatory rigidity}

It could also be that the failure of credit risk models was caused by the need to comply with rigid regulatory standards, rather than by misaligned incentives. Regulators required banks to stick to

\footnotetext{
${ }^{33}$ Based on conversations with supervisors, there is no evidence of banks overreporting estimated default rates during the approval process.
} 
the models that were approved and this took away some discretion from the banks and reduced their ability to adapt to changing times. While banks had the flexibility to adjust the PDs and other parameters if banks felt they were incorrect, a large amount of such adjustments would draw some flak from the regulator. Thus, it could be the lack of discretion that came with the regulation which led to the failure of models, rather than misaligned incentives. It could further be that interest rates did a better job at predicting defaults because banks had the flexibility to adjust their own risk models to the new information. Our results oppose such a story. We find that more discretion given to the banks implies larger underperformance of credit risk models. Under the F-IRB approach, banks only have flexibility to use model generated PDs, while LGD and EAD are given by the regulator and hard-wired into the risk-weight calculation. Under the A-IRB approach, banks also have the choice to use their own model generated parameters for LGD and EAD. This accorded more discretion to the banks. Interestingly, we find that more autonomy implies a higher degree of incongruence between reported risk-weights and actual loan losses.

\section{Conclusion}

With this paper, we contribute to the discussion on regulatory complexity. Using data from the German credit register, we show that the introduction of Basel II-type, model-based capital regulation affected the validity of banks' internal risk estimates. We find that for the same firm in the same year, both reported PDs and risk-weights are significantly lower, while estimation errors and loan losses are significantly higher for loans under the new regulatory approach. Thus, risk estimates for loans under the model-based approach systematically underestimate actual default rates. There is an incongruence between the reported PDs/risk-weights and interest rates charged for loans under model-based regulation, suggesting that banks were aware of the inherent riskiness of these loan portfolios. To account for potential differences in the correlation structure in the IRB and SA pools, we look at aggregate results. We find a significant underestimation of default rates and higher loss rates in the IRB pool, which tells us that better diversification in IRB portfolios compared with SA portfolios does not solve the underestimation problem. All in all, our results suggest that simpler rules may have their benefits, and encourage caution against the current trend towards higher complexity of financial regulation.

Importantly, our paper does not make any welfare statements about model-based regulation. 
While we observe that banks underestimate the level of risk, it could be that the reform positively affected the cross-sectional predictability of defaults within the pool of IRB loans. Moreover, we demonstrated that lower capital charges for loans under model-based regulation promoted lending by large banks, with potentially beneficial effects for certain borrowers. We do not make a judgment on these aspects of model-based regulation. Rather, we benchmark the reform against its stated objectives and conclude that complex, model-based regulation did not succeed in tying capital charges to actual asset risk. Counter to the stated objective of the reform, aggregate credit risk of financial institutions has increased.

Our findings can be explained by incentives for banks to underreport PDs in order to economize on regulatory capital. This interpretation is supported by the fact that interest rates, in contrast to PDs/risk-weights, seem to reflect borrowers' actual default risk, and by the fact that the underreporting of PDs is more severe for low PD loans, for which small reductions in the PD translate into large reductions in risk-weights. While we do not analyze the effect of model-based regulation on overall systemic risk, it is very likely that the stability of the financial sector as a whole has been adversely affected. Clearly, the reform induced a considerable reduction in capital requirements while actual loan losses have been higher for loans under the new regulation. It is likely that lower capital buffers under the new regime increased banks' vulnerability to credit risk shocks.

Our findings raise important questions about political economy factors that might play a role in the introduction of complex regulation. While the political economy side of complexity is not the focus of this paper, our results support the regulatory capture view of regulation (Stigler 1971, Posner 1975, Peltzman 1976, Becker 1983, Shleifer and Vishny 2002). The high compliance costs associated with the model-based approach meant that only the larger banks adopted this new approach and consequently benefited from lower capital charges. Moreover, one could argue, regulators also benefited from the introduction of complex regulation, as it facilitates what can be termed as regulatory 'empire building' à la Jensen and Meckling (1976). The number of financial supervisors has dramatically increased around the world, at a much faster pace than the number of people working in the financial industry (Haldane 2013). ${ }^{34}$ The political economy of complex financial regulation remains an interesting topic for further research.

\footnotetext{
${ }^{34}$ The most recent step in this direction was the creation of about 1,000 new supervisory positions at the European Central Bank.
} 


\section{References}

Acharya, V. (2011). Ring-fencing is good, but no panacea. In The Future of Banking (edited by Thorsten Beck). Vox eBook.

Acharya, V., Engle, R., and Pierret, D. (2014). Testing macroprudential stress tests: The risk of regulatory risk weights. Journal of Monetary Economics, forthcoming.

Admati, A. and Hellwig, M. (2013). The bankers' new clothes: What's wrong with banking and what to do about it. Princeton University Press.

Bachmann, R. and Bayer, C. (2014). Investment dispersion and the business cycle. American Economic Review, 104(4):1392-1416.

Basel Committee on Banking Supervision (1988). International convergence of capital measurement and capital standards. Bank for International Settlements, Basel, Switzerland.

Basel Committee on Banking Supervision (1999). Capital requirements and bank behaviour: The impact of the Basle Accord. Bank for International Settlements, Basel, Switzerland.

Basel Committee on Banking Supervision (2004). Implementation of Basel II: Practical considerations. Bank for International Settlements, Basel, Switzerland.

Basel Committee on Banking Supervision (2005). An explanatory note on the Basel II IRB risk weight functions. Bank for International Settlements, Basel, Switzerland.

Basel Committee on Banking Supervision (2006). International convergence of capital measurement and capital standards - A revised framework. Bank for International Settlements, Basel, Switzerland.

Basel Committee on Banking Supervision (2013). Regulatory consistency assessment programme (RCAP): Analysis of risk-weighted assets for credit risk in the banking book. Bank for International Settlements, Basel, Switzerland.

Becker, B. and Opp, M. (2014). Regulatory reform and risk-taking. Working Paper.

Becker, G. (1983). A theory of competition among pressure groups for political influence. Quarterly Journal of Economics, 98(3):371-400. 
Behn, M., Haselmann, R., and Wachtel, P. (2014). Pro-cyclical capital regulation and lending. Working Paper.

Brinkmann, E. J. and Horvitz, P. M. (1995). Risk-based capital standards and the credit crunch. Journal of Money, Credit and Banking, 27(3):848-863.

Brun, M., Fraisse, H., and Thesmar, D. (2013). The real effects of bank capital requirements. HEC Paris Research Paper.

Bundesbank (2003). Approaches to the validation of internal rating systems. Monthly Report September, pages 59-71.

Bundesbank (2004). New capital requirements for credit institutions (Basel II). Monthly Report September, pages 73-94.

Daníelsson, J., Embrechts, P., Goodhart, C., Keating, C., Muennich, F., Renault, O., and Shin, H. S. (2001). An academic response to Basel II. LSE Financial Markets Group, Special Paper No. 130.

Das, S. and Sy, A. (2012). How risky are banks' risk weighted assets? Evidence from the financial crisis. IMF Working Paper.

Demirgüç-Kunt, A., Detragiache, E., and Merrouche, O. (2013). Bank capital: Lessons from the financial crisis. Journal of Money, Credit and Banking, 45(6):1147-1164.

Duellmann, K. and Koziol, P. (2014). Are SME loans less risky than regulatory capital requirements suggest? Journal of Fixed Income, 23(4):89-103.

Firestone, S. and Rezende, M. (2013). Are banks' internal risk parameters consistent? Evidence from syndicated loans. Working Paper.

Glaeser, E. and Shleifer, A. (2001). A reason for quantity regulation. American Economic Review, 91(2):431-435.

Goel, A. and Thakor, A. (2014). Information reliability and welfare: A theory of coarse credit ratings. Journal of Financial Economics, forthcoming.

Hagendorff, J. and Vallascas, F. (2013). The risk sensitivity of capital requirements: Evidence from an international sample of large banks. Review of Finance, forthcoming. 
Haldane, A. (2011). Capital discipline. Available online: http://www.bankofengland.co.uk/ publications/Documents/speeches/2011/speech484.pdf. Bank of England, Speech on 9 January.

Haldane, A. (2012). The dog and the frisbee. Available online: http://www.bankofengland.co.uk/ publications/Documents/speeches/2012/speech596.pdf. Bank of England, Speech on 31 August.

Haldane, A. (2013). Constraining discretion in bank regulation. Available online: http://www. bankofengland.co.uk/publications/Documents/speeches/2013/speech657.pdf. Bank of England, Speech on 9 April.

Halvorsen, R. and Palmquist, R. (1980). The interpretation of dummy variables in semilogarithmic equations. American Economic Review, 70(3):474-475.

Hellwig, M. (2010). Capital regulation after the crisis: Business as usual? CESifo DICE Report, $8(2): 40-46$.

Hoenig, T. (2010). Banking: From Bagehot to Basel, and back again. Available online: http:// www.bankofengland.co.uk/publications/Documents/speeches/2010/speech455.pdf. Bank of England, Speech on 25 October.

Hoenig, T. (2013). Basel III capital: A well-intended illusion. Available online: http://www.fdic. gov/news/news/speeches/spapr0913.html. FDIC, Speech on 9 April.

Holmström, B. and Milgrom, P. (1991). Multitask principal-agent analyses: Incentive contracts, asset ownership, and job design. Journal of Law, Economics, and Organization, 7:24-52.

Jensen, M. C. and Meckling, W. H. (1976). Theory of the firm: Managerial behavior, agency costs and ownership structure. Journal of Financial Economics, 3(4):305-360.

Jones, D. (2000). Emerging problems with the Basel capital accord: Regulatory capital arbitrage and related issues. Journal of Banking and Finance, 24(1):35-58.

Kane, E. (1977). Good intentions and unintended evil: The case against selective credit allocation. Journal of Money, Credit and Banking, 9(1):55-69.

Kashyap, A. K. and Stein, J. C. (2004). Cyclical implications of the Basel II capital standards. Federal Reserve Bank of Chicago: Economic Perspectives, (1):18-31.

Khwaja, A. I. and Mian, A. (2008). Tracing the impact of bank liquidity shocks: Evidence from an emerging market. American Economic Review, 98(4):1413-1442. 
Koijen, R. and Yogo, M. (2014a). The cost of financial frictions for life insurers. American Economic Review, forthcoming.

Koijen, R. and Yogo, M. (2014b). Shadow insurance. Working Paper.

Krahnen, J. P. and Weber, M. (2001). Generally accepted rating principles: A primer. Journal of Banking and Finance, 25(1):3-23.

Le Leslé, V. and Avramova, S. (2012). Revisiting risk-weighted assets. IMF Working Paper.

Mariathasan, M. and Merrouche, O. (2014). The manipulation of Basel risk weights. Journal of Financial Intermediation, 23(3):300-321.

Moody's Analytics (2013). Riskcalc ${ }^{T M}$ plus.

Peltzman, S. (1976). Toward a more general theory of regulation. Journal of Law and Economics, 19(2):211-240.

Posner, R. (1975). Social costs of monopoly and regulation. Journal of Political Economy, 83(4):807-827.

Rajan, U., Seru, A., and Vig, V. (2012). The failure of models that predict failure: Distance, incentives and defaults. Journal of Financial Economics, forthcoming.

Shleifer, A. and Vishny, R. (2002). The grabbing hand: Government pathologies and their cures. Harvard University Press.

Solvabilitätsverordnung (2006). Verordnung über die angemessene Eigenmittelausstattung von Instituten, Institutsgruppen und Finanzholding-Gruppen. Bundesministerium für Finanzen, Berlin, Germany.

Stigler, G. J. (1971). The theory of economic regulation. The Bell Journal of Economics and Management Science, 2(1):3-21. 


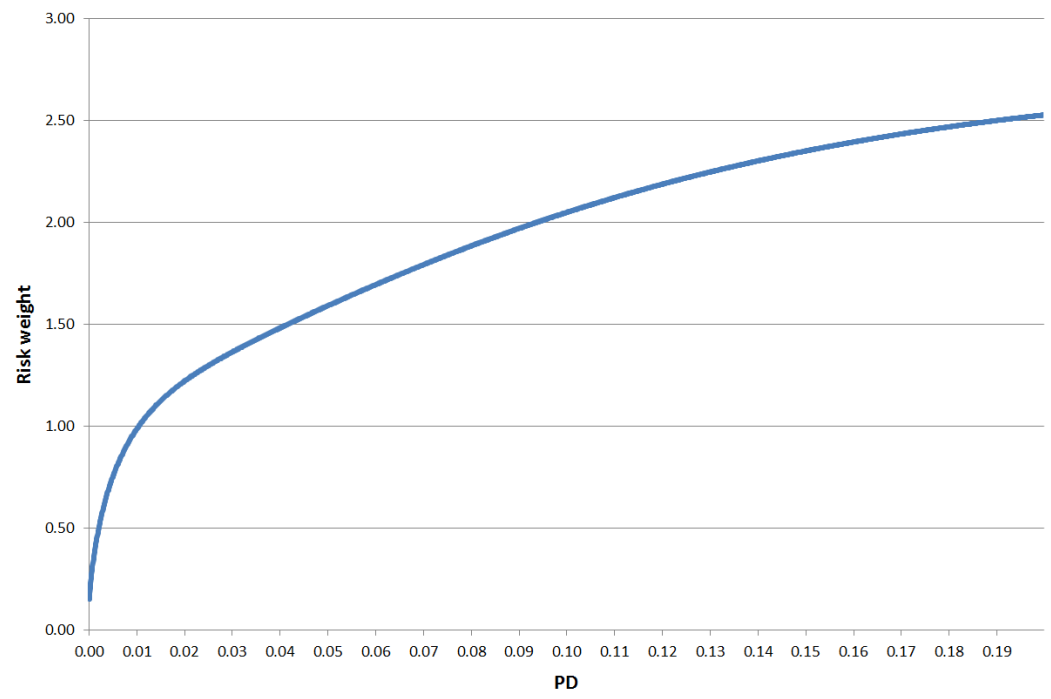

Figure 1: PDs and regulatory risk-weights

This figure shows how estimated PDs map into regulatory risk-weights for loans in the corporate sector, assuming standard values for loss given default ( 45 percent) and loan maturity ( 2.5 years). The figure plots riskweights for loans to firms with a turnover larger than $€ 50$ million. For loans to smaller firms, risk-weights are multiplied with a correction factor depending on the exact amount of the turnover.

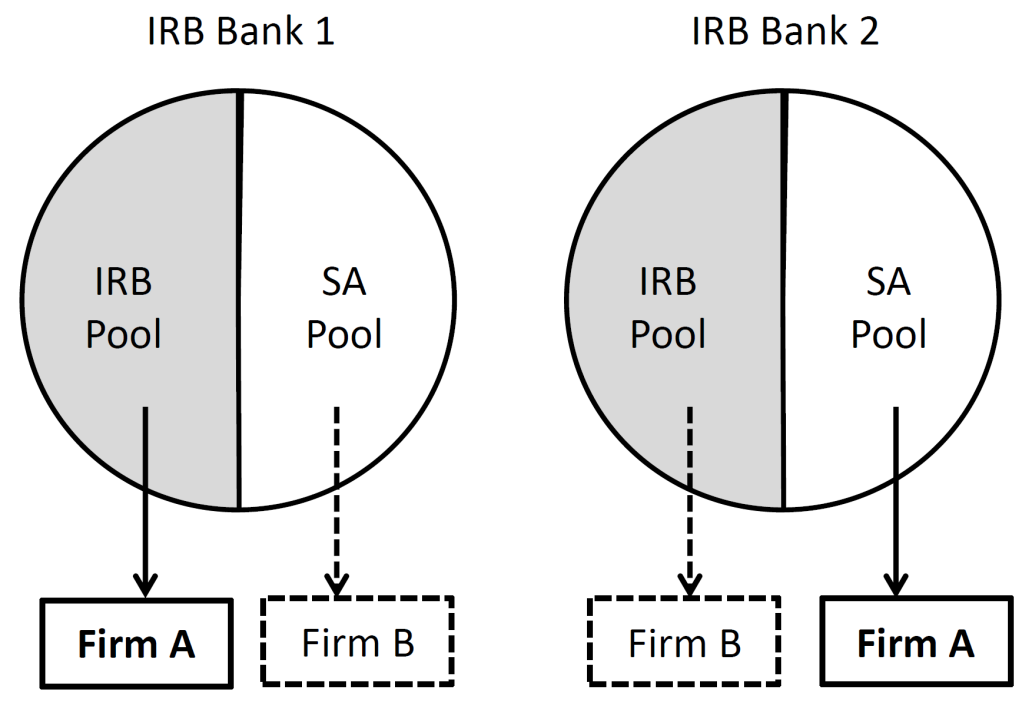

Figure 2: Identification strategy

This figure illustrates our identification strategy. As the implementation of IRB occurs gradually, IRB banks have both IRB and SA loans in their portfolios. In the regression analysis, we rely on firms that have at least two loans from different IRB banks: one bank where the loan is in the IRB pool and one bank where the loan is the SA pool. 
PD

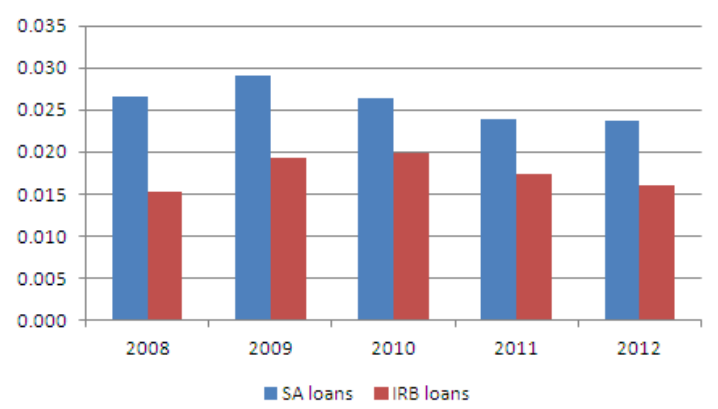

RWA toloans

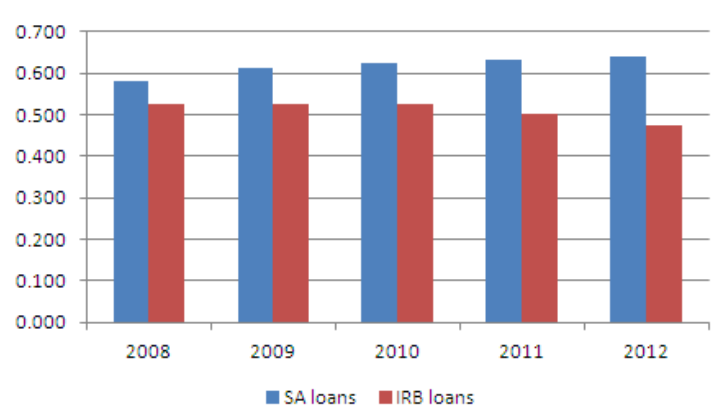

Actual default

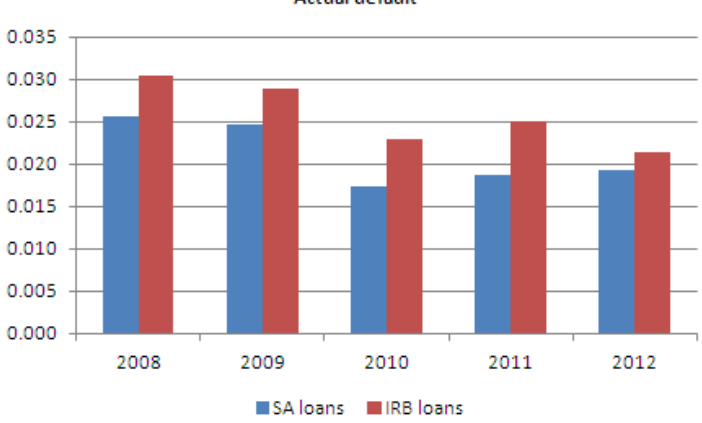

Loss rate

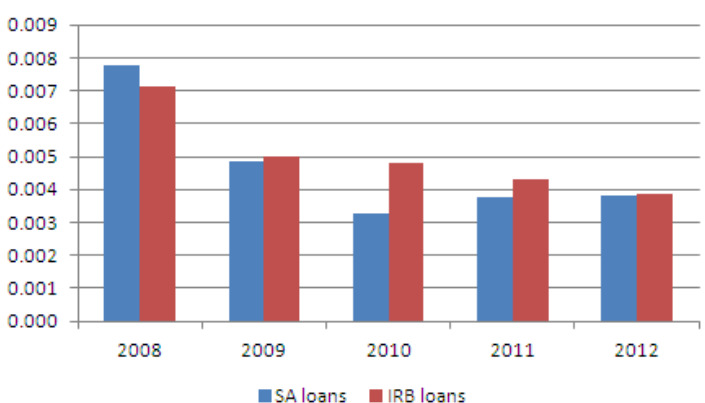

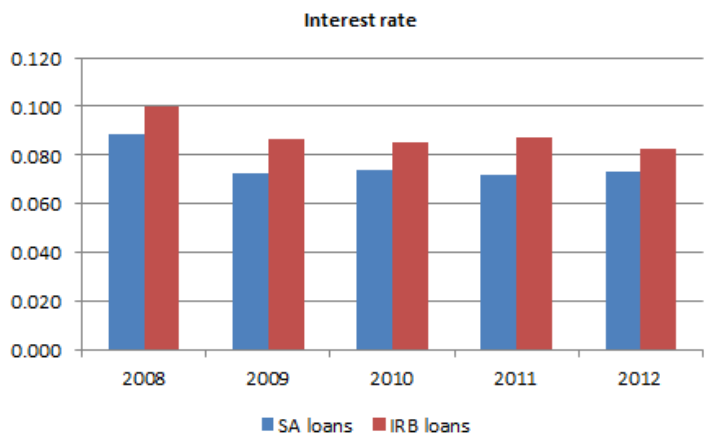

Figure 3: Average PDs and actual default rates

This figure shows average PDs, actual default rates, loan loss rates, the ratio of RWA TO LOAN, and interest rates for SA loans and IRB loans during the period from 2008 to 2012. The sample includes all loans that are not in default in the respective year. 

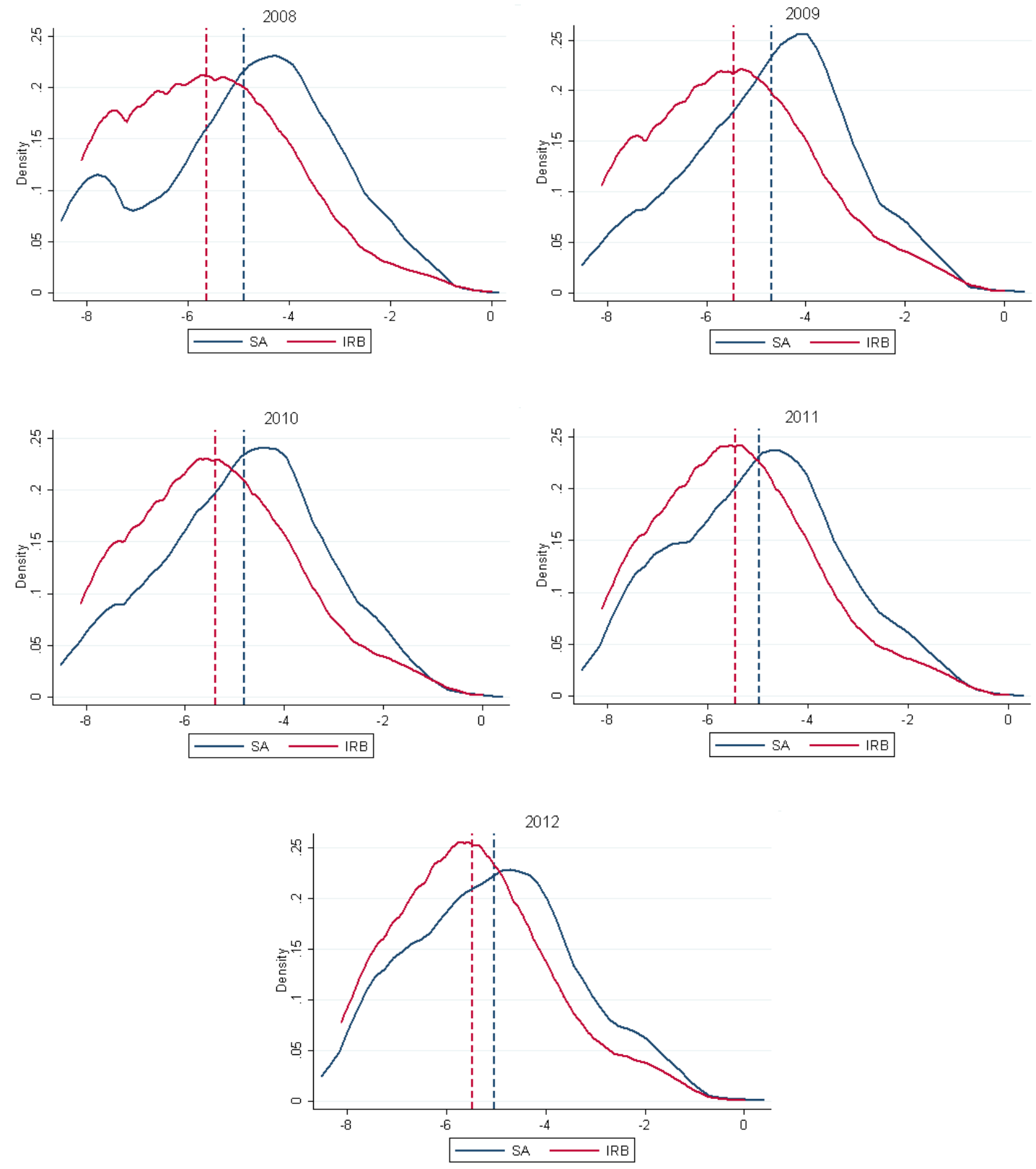

Figure 4: PD kernel densities

This figure shows Epanechnikov kernel densities for PDs from 2008 to 2012. PDs are reported in logarithms. The smoothing parameter in the density estimation is set to 0.4. The blue line corresponds to PDs for SA loans of IRB banks, the red line corresponds to IRB loans of IRB banks. Dashed vertical lines represent the respective mean of the distribution. 


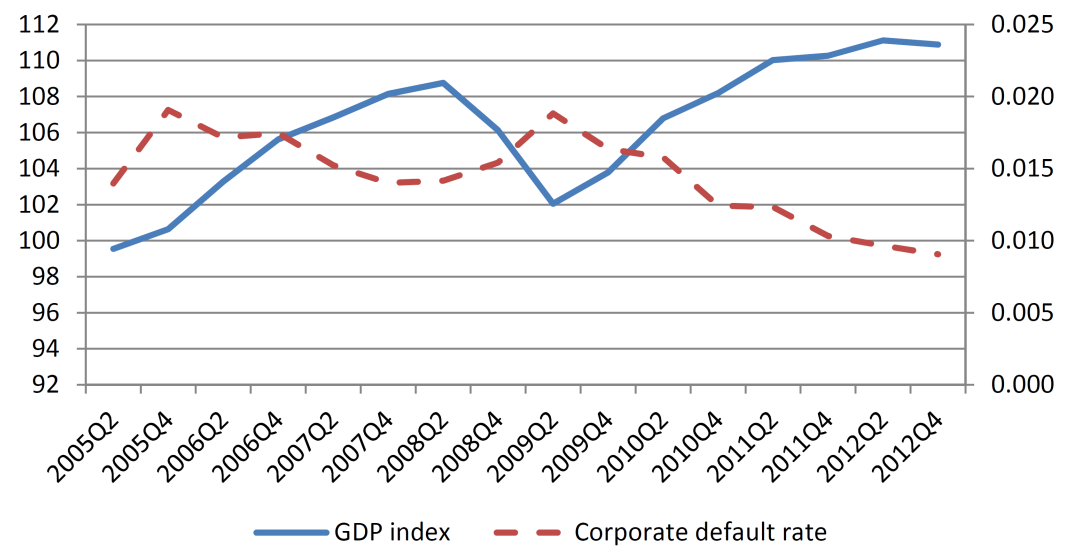

Figure 5: Business cycle

This figure shows the development of the seasonally adjusted German GDP index between 2005Q1 and 2012Q4 (left axis; source: German Federal Statistical Office) and the development of default rates in the German corporate sector (right axis; source: Duellmann and Koziol 2014). 
PD

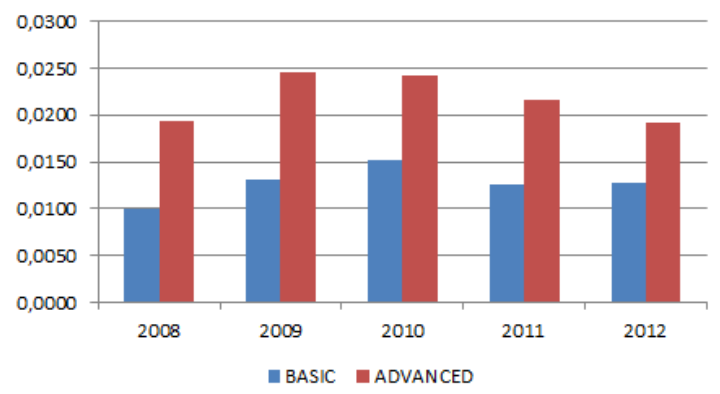

RWA to loans

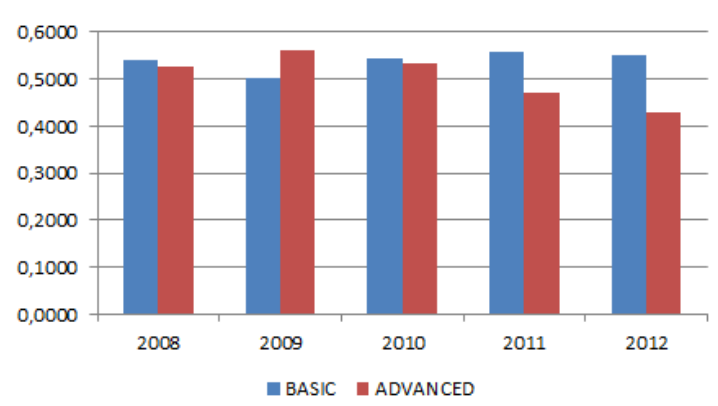

Actual default

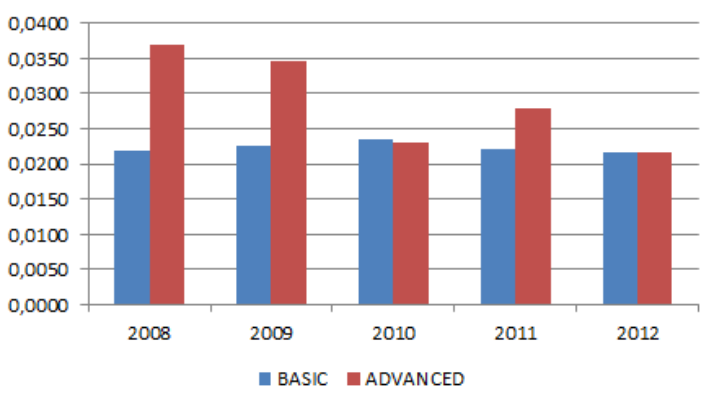

Loss rate

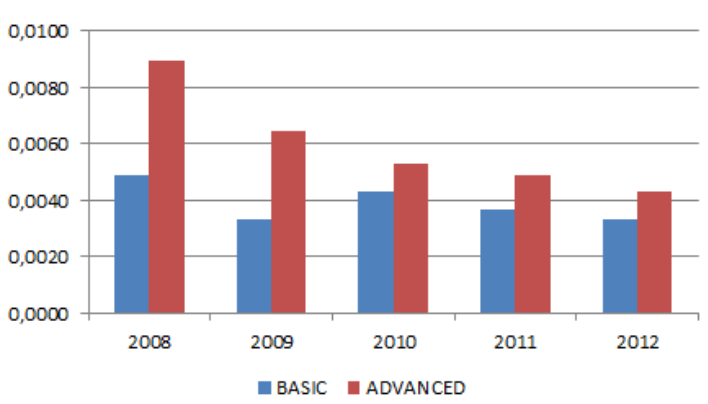

Interest rate

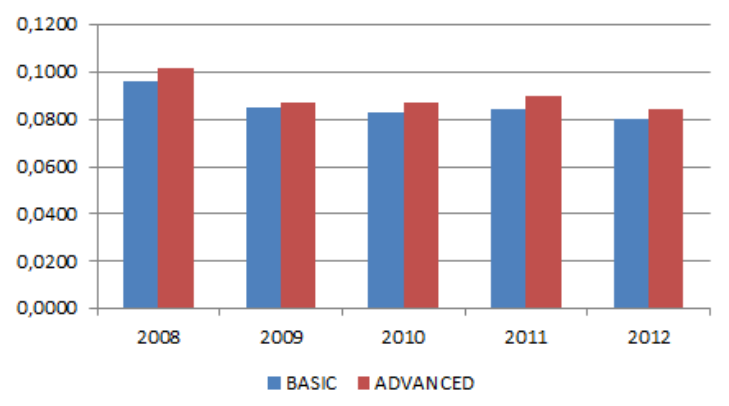

Figure 6: Basic vs. advanced IRB approach

This figure shows average PDs, actual default rates, loan loss rates, the ratio of RWA TO LOAN, and interest rates for loans under the basic and the advanced IRB approaches during the period from 2008 to 2012. The sample includes all loans that are not in default in the respective year. 


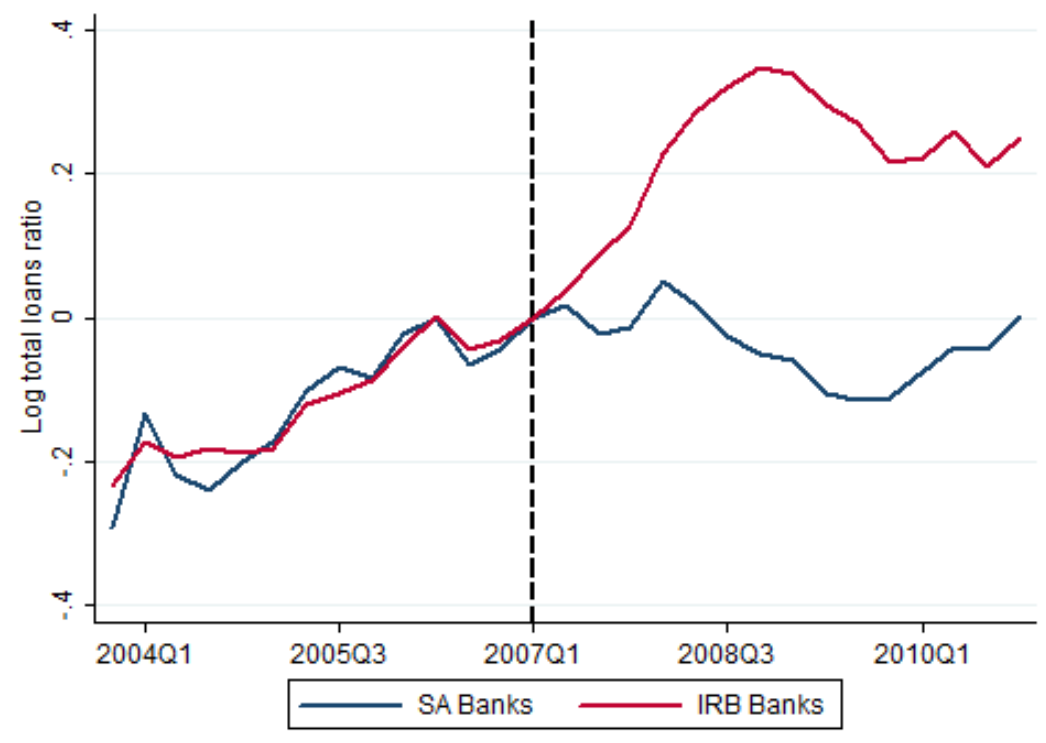

Figure 7: Aggregate lending around the Basel II introduction

This figure shows the development of aggregate lending in our sample for SA banks and IRB banks around the Basel II introduction in the first quarter of 2007. Aggregate numbers are obtained from the German credit register and calculated by summing all loans from the respective group of banks within a given quarter. Aggregate loans are standardized by their value in 2007Q1, and the figure shows the logarithm of this ratio (see Khwaja and Mian 2008 for a similar graphical illustration). 
Table 1: Descriptives

\begin{tabular}{|c|c|c|c|c|}
\hline \multicolumn{5}{|l|}{ Panel A: Bank descriptives } \\
\hline & \multicolumn{2}{|c|}{ SA banks (1,558 banks) } & \multicolumn{2}{|c|}{ IRB banks (45 banks) } \\
\hline & Mean & S.D. & Mean & S.D. \\
\hline BANK ASSETS $(2006$, in mn €) & 1,330 & 3,750 & 133,000 & 259,000 \\
\hline LOG BANK ASSETS (2006) & 20.158 & 1.162 & 24.196 & 1.937 \\
\hline BANK EQUITY RATIO (2006) & 6.366 & 4.202 & 4.246 & 2.471 \\
\hline BANK ROA (2006) & 0.680 & 0.464 & 0.673 & 0.584 \\
\hline \multicolumn{5}{|c|}{ Panel B: Loan descriptives } \\
\hline & \multicolumn{2}{|c|}{ SA loans $(59,000$ loans $)$} & \multicolumn{2}{|c|}{ IRB loans $(237,985$ loans $)$} \\
\hline & Mean & S.D. & Mean & S.D. \\
\hline PD & 0.0262 & 0.0564 & 0.0176 & 0.0506 \\
\hline RWA TO LOAN & 0.6155 & 0.7558 & 0.4900 & 0.5374 \\
\hline LOSS RATE & 0.0049 & 0.0542 & 0.0051 & 0.0546 \\
\hline INTEREST RATE & 0.0773 & 0.0559 & 0.0887 & 0.0601 \\
\hline$\Delta$ LOG(LOANS) & 0.0159 & 0.3582 & 0.0644 & 0.5697 \\
\hline \multicolumn{5}{|c|}{ Panel C: Firm descriptives } \\
\hline \multicolumn{5}{|c|}{ (5,961 firms) } \\
\hline & Mean & S.D. & & \\
\hline FIRM ASSETS (2006, in mn €) & 154 & 817 & & \\
\hline FIRM DEBT TO ASSETS (2006) & 0.343 & 0.202 & & \\
\hline LOG FIRM ASSETS (2006) & 10.363 & 1.428 & & \\
\hline FIRM ROA (2006) & 7.909 & 6.982 & & \\
\hline
\end{tabular}

Panel A shows descriptive statistics for the groups of SA and IRB banks. An IRB bank is defined as a bank that uses the internal ratings-based approach for some loans during our sample period, whereas an SA bank is defined as a bank that uses the Basel II standard approach in all its lending relationships. Panel B shows summary statistics for loans in the German credit register. Data are restricted to (a) loans that are larger than $€ 1.5$ million (b) loans from commercial, state, or cooperative banks that are subject to the Basel II capital regulation. $\Delta$ LOG(LOANS) refers to the change in the log of loans around the Basel II reform (average of two years after minus average of two years before the reform). The remaining variables include observations from 2008 to 2012. Panel C contains information on the firm level for a matched sample of 5,961 firms. Firm balance sheet information is obtained from Bundesbank's USTAN database. 


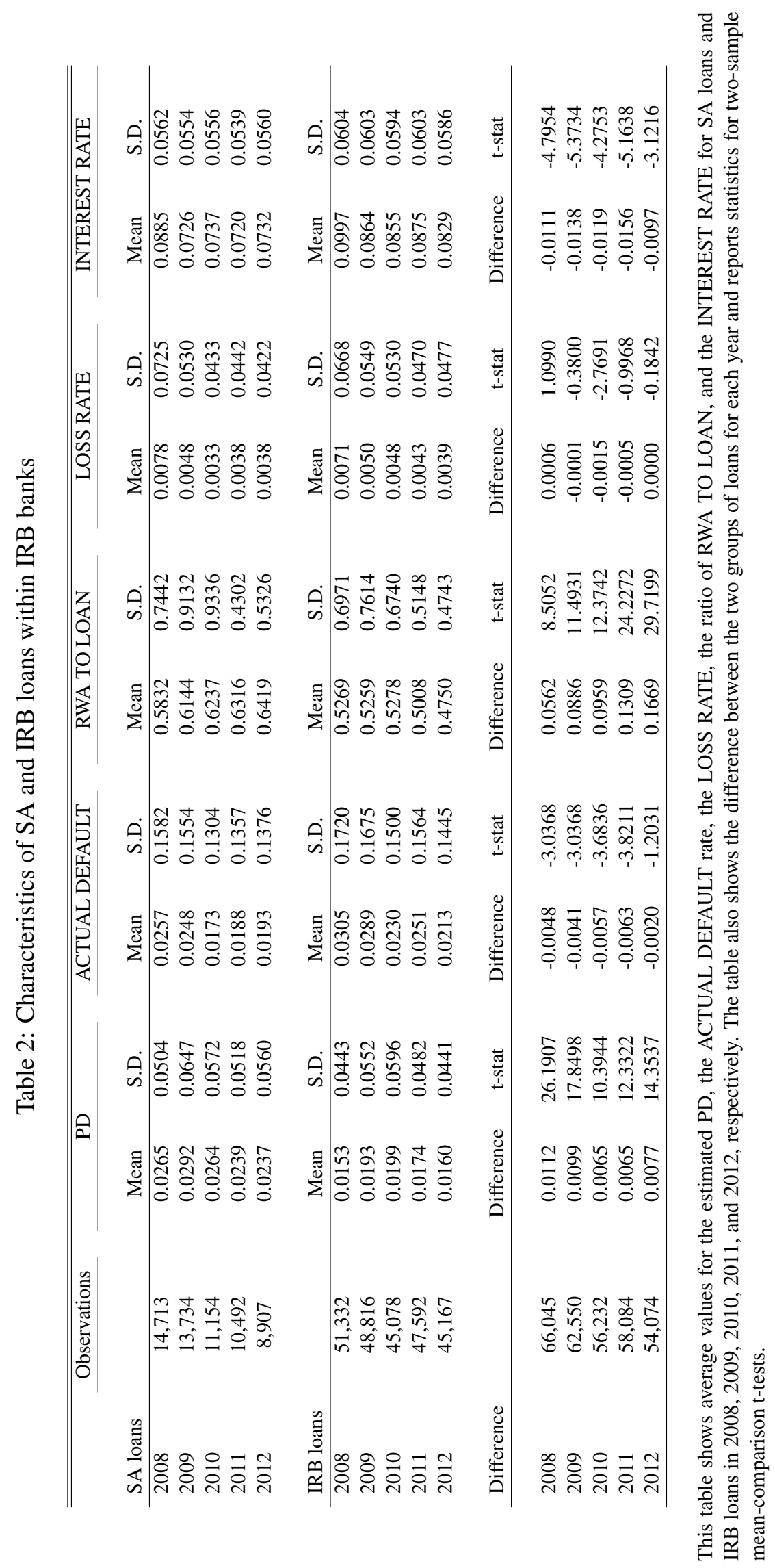


Table 3: PD

\begin{tabular}{lccccc}
\hline \hline Dependent variable: & \multicolumn{5}{c}{ LOG(PD) } \\
\cline { 2 - 6 } & $(1)$ & $(2)$ & $(3)$ & $(4)$ & $(5)$ \\
\hline & & & & & \\
D(IRB LOAN) & $-5.5494^{* * *}$ & $-0.3363^{* * *}$ & $-0.3538^{* * *}$ & $-0.3453^{* * *}$ & $-0.2516^{* * *}$ \\
& $(0.0974)$ & $(0.0495)$ & $(0.0492)$ & $(0.0536)$ & $(0.0510)$ \\
& & & & & \\
D(SA LOAN) & $-4.9515^{* * *}$ & & & & \\
& $(0.1624)$ & & & & \\
Firm FE & NO & YES & YES & - & - \\
Year FE & NO & NO & YES & - & - \\
Firm $\times$ year FE & NO & NO & NO & YES & YES \\
Bank $\times$ year FE & NO & NO & NO & NO & YES \\
Observations & 296,985 & 296,985 & 296,985 & 50,798 & 50,798 \\
R-squared & 0.0192 & 0.7280 & 0.7321 & 0.7117 & 0.7508 \\
\hline
\end{tabular}

The sample includes loans from IRB banks in 2008, 2009, 2010, 2011, and 2012. The dependent variable in all regressions is the logarithm of the loan-specific PD. In columns 4 and 5, the sample is restricted to firm-year observations in which the respective firm has at least one IRB loan and at least one SA loan. D(IRB LOAN) indicates the regulatory approach under which a specific loan was issued and is equal to 1 if the loan was issued under IRB. Similarly, D(SA LOAN) is equal to 1 if the loan was issued under SA and 0 otherwise. Robust standard errors adjusted for double clustering at the bank and year level are reported in parentheses. Note: * indicates statistical significance at the $10 \%$ level, ** at the $5 \%$ level and $* * *$ at the $1 \%$ level.

Table 4: Estimation error

\begin{tabular}{|c|c|c|c|c|c|}
\hline \multirow[t]{2}{*}{ Dependent variable: } & \multicolumn{5}{|c|}{ ESTIMATION ERROR (ACTUAL DEFAULT - PD) } \\
\hline & (1) & (2) & (3) & (4) & (5) \\
\hline D(IRB LOAN) & $\begin{array}{l}0.0084^{*} \\
(0.0044)\end{array}$ & $\begin{array}{c}0.0066 * * \\
(0.0027)\end{array}$ & $\begin{array}{l}0.0046^{*} \\
(0.0024)\end{array}$ & $\begin{array}{c}0.0071 * * * \\
(0.0027)\end{array}$ & $\begin{array}{c}0.0052^{* *} \\
(0.0024)\end{array}$ \\
\hline D(SA LOAN) & $\begin{array}{l}-0.0045 \\
(0.0074)\end{array}$ & & & & \\
\hline Firm FE & NO & YES & YES & - & - \\
\hline Year FE & NO & NO & YES & - & - \\
\hline Firm $\times$ year FE & NO & NO & NO & YES & YES \\
\hline Bank $\times$ year FE & NO & NO & NO & NO & YES \\
\hline Observations & 296,985 & 296,985 & 296,985 & 50,798 & 50,798 \\
\hline R-squared & 0.0011 & 0.4937 & 0.4975 & 0.6241 & 0.6312 \\
\hline
\end{tabular}

The sample includes loans from IRB banks in 2008, 2009, 2010, 2011, and 2012. The dependent variable in all regressions is the loan-specific ESTIMATION ERROR, defined as the difference between an ACTUAL DEFAULT dummy that indicates whether the loan defaults within the next four quarters and the PD. In columns 4 and 5, the sample is restricted to firm-year observations in which the respective firm has at least one IRB loan and at least one SA loan. D(IRB LOAN) indicates the regulatory approach under which a specific loan was issued and is equal to 1 if the loan was issued under IRB. Similarly, D(SA LOAN) is equal to 1 if the loan was issued under SA and 0 otherwise. Robust standard errors adjusted for double clustering at the bank and year level are reported in parentheses. Note: * indicates statistical significance at the $10 \%$ level, ** at the $5 \%$ level and $* * *$ at the $1 \%$ level. 
Table 5: RWA to loan

\begin{tabular}{lccccc}
\hline \hline Dependent variable: & \multicolumn{5}{c}{ RWA TO LOAN } \\
\cline { 2 - 6 } & $(1)$ & $(2)$ & $(3)$ & $(4)$ & $(5)$ \\
\hline & & & & & \\
D(IRB LOAN) & $0.5114^{* * *}$ & $-0.1371^{* * *}$ & $-0.1372^{* * *}$ & $-0.1268^{* * *}$ & $-0.1522^{* * *}$ \\
& $(0.0302)$ & $(0.0418)$ & $(0.0416)$ & $(0.0432)$ & $(0.0460)$ \\
& & & & & \\
D(SA LOAN) & $0.6155^{* * *}$ & & & & \\
& $(0.0538)$ & & & & \\
Firm FE & NO & YES & YES & - & - \\
Year FE & NO & NO & YES & - & - \\
Firm $\times$ year FE & NO & NO & NO & YES & YES \\
Bank $\times$ year FE & NO & NO & NO & NO & YES \\
Observations & 281,565 & 281,565 & 281,565 & 47,469 & 47,469 \\
R-squared & 0.0039 & 0.5589 & 0.5591 & 0.2738 & 0.2983 \\
\hline
\end{tabular}

The sample includes loans from IRB banks in 2008, 2009, 2010, 2011, and 2012. The dependent variable in all regressions is the loan-specific ratio of RWA TO LOAN. In columns 4 and 5, the sample is restricted to firm-year observations in which the respective firm has at least one IRB loan and at least one SA loan. D(IRB LOAN) indicates the regulatory approach under which a specific loan was issued and is equal to 1 if the loan was issued under IRB. Similarly, D(SA LOAN) is equal to 1 if the loan was issued under SA and 0 otherwise. Robust standard errors adjusted for double clustering at the bank and year level are reported in parentheses. Note: * indicates statistical significance at the $10 \%$ level, ** at the $5 \%$ level and $* * *$ at the $1 \%$ level.

Table 6: Loss rate

\begin{tabular}{|c|c|c|c|c|c|}
\hline \multirow[t]{2}{*}{ Dependent variable: } & \multicolumn{5}{|c|}{ LOSS RATE } \\
\hline & (1) & (2) & (3) & (4) & (5) \\
\hline D(IRB LOAN) & $\begin{array}{c}0.0051 * * * \\
(0.0009)\end{array}$ & $\begin{array}{c}0.0013 * * * \\
(0.0004)\end{array}$ & $\begin{array}{l}0.0009 * \\
(0.0005)\end{array}$ & $\begin{array}{c}0.0012 * \\
(0.0006)\end{array}$ & $\begin{array}{c}0.0008 \\
(0.0005)\end{array}$ \\
\hline D(SA LOAN) & $\begin{array}{c}0.0049 * * * \\
(0.0017)\end{array}$ & & & & \\
\hline Firm FE & $\mathrm{NO}$ & YES & YES & 一 & - \\
\hline Year FE & $\mathrm{NO}$ & NO & YES & 一 & - \\
\hline Firm $\times$ year FE & $\mathrm{NO}$ & NO & NO & YES & YES \\
\hline Bank $\times$ year $\mathrm{FE}$ & NO & NO & $\mathrm{NO}$ & NO & YES \\
\hline Observations & 294,592 & 294,592 & 294,592 & 50,543 & 50,543 \\
\hline R-squared & 0.0084 & 0.5830 & 0.5847 & 0.7050 & 0.7076 \\
\hline
\end{tabular}

The sample includes loans from IRB banks in 2008, 2009, 2010, 2011, and 2012. The dependent variable in all regressions is the loan-specific LOSS RATE. In columns 4 and 5, the sample is restricted to firm-year observations in which the respective firm has at least one IRB loan and at least one SA loan. D(IRB LOAN) indicates the regulatory approach under which a specific loan was issued and is equal to 1 if the loan was issued under IRB. Similarly, D(SA LOAN) is equal to 1 if the loan was issued under SA and 0 otherwise. Robust standard errors adjusted for double clustering at the bank and year level are reported in parentheses. Note: * indicates statistical significance at the $10 \%$ level, ** at the $5 \%$ level and $* * *$ at the $1 \%$ level. 
Table 7: Interest rate

\begin{tabular}{lccccc}
\hline \hline Dependent variable: & \multicolumn{5}{c}{ INTEREST RATE } \\
\cline { 2 - 6 } & $(1)$ & $(2)$ & $(3)$ & $(4)$ & $(5)$ \\
\hline \multirow{2}{*}{ D(IRB LOAN) } & $0.0885^{* * *}$ & $0.0054^{* * *}$ & $0.0078^{* * *}$ & $0.0097 * * *$ & $0.0198^{* * *}$ \\
& $(0.0027)$ & $(0.0013)$ & $(0.0013)$ & $(0.0020)$ & $(0.0049)$ \\
& & & & \\
D(SA LOAN) & $0.0798^{* * *}$ & & & & \\
& $(0.0038)$ & & & & - \\
Firm FE & NO & YES & YES & - & - \\
Year FE & NO & NO & YES & YES & YES \\
Firm $\times$ year FE & NO & NO & NO & NO & YES \\
Bank $\times$ year FE & NO & NO & NO & 1,677 & 1,677 \\
Observations & 11,811 & 11,811 & 11,811 & 0.8037 & 0.8279 \\
R-squared & 0.0027 & 0.6927 & 0.7016 & & \\
\hline
\end{tabular}

The sample includes loans from IRB banks in 2008, 2009, 2010, 2011, and 2012. The dependent variable in all regressions is the loan-specific INTEREST RATE. In columns 4 and 5, the sample is restricted to firm-year observations in which the respective firm has at least one IRB loan and at least one SA loan. D(IRB LOAN) indicates the regulatory approach under which a specific loan was issued and is equal to 1 if the loan was issued under IRB. Similarly, D(SA LOAN) is equal to 1 if the loan was issued under SA and 0 otherwise. Robust standard errors adjusted for double clustering at the bank and year level are reported in parentheses. Note: * indicates statistical significance at the $10 \%$ level, ** at the $5 \%$ level and $* * *$ at the $1 \%$ level. 


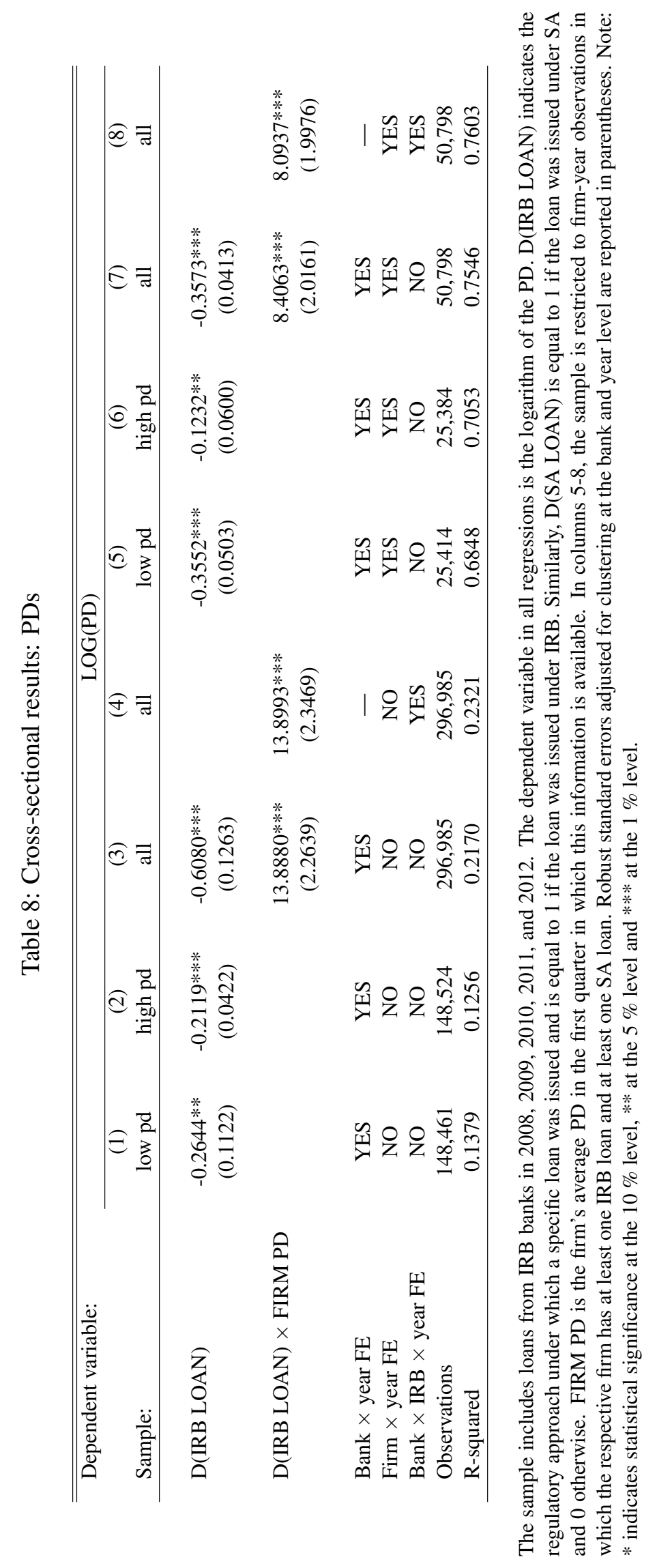




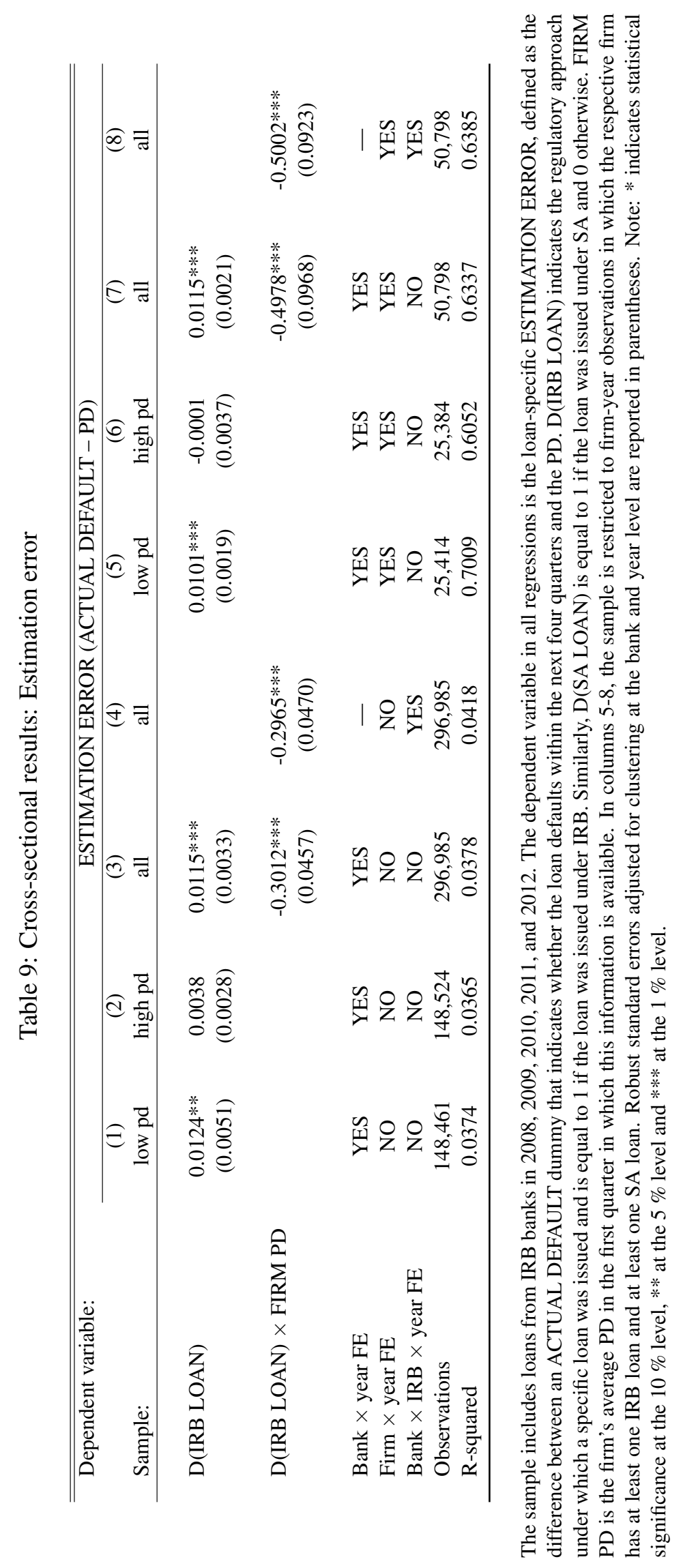




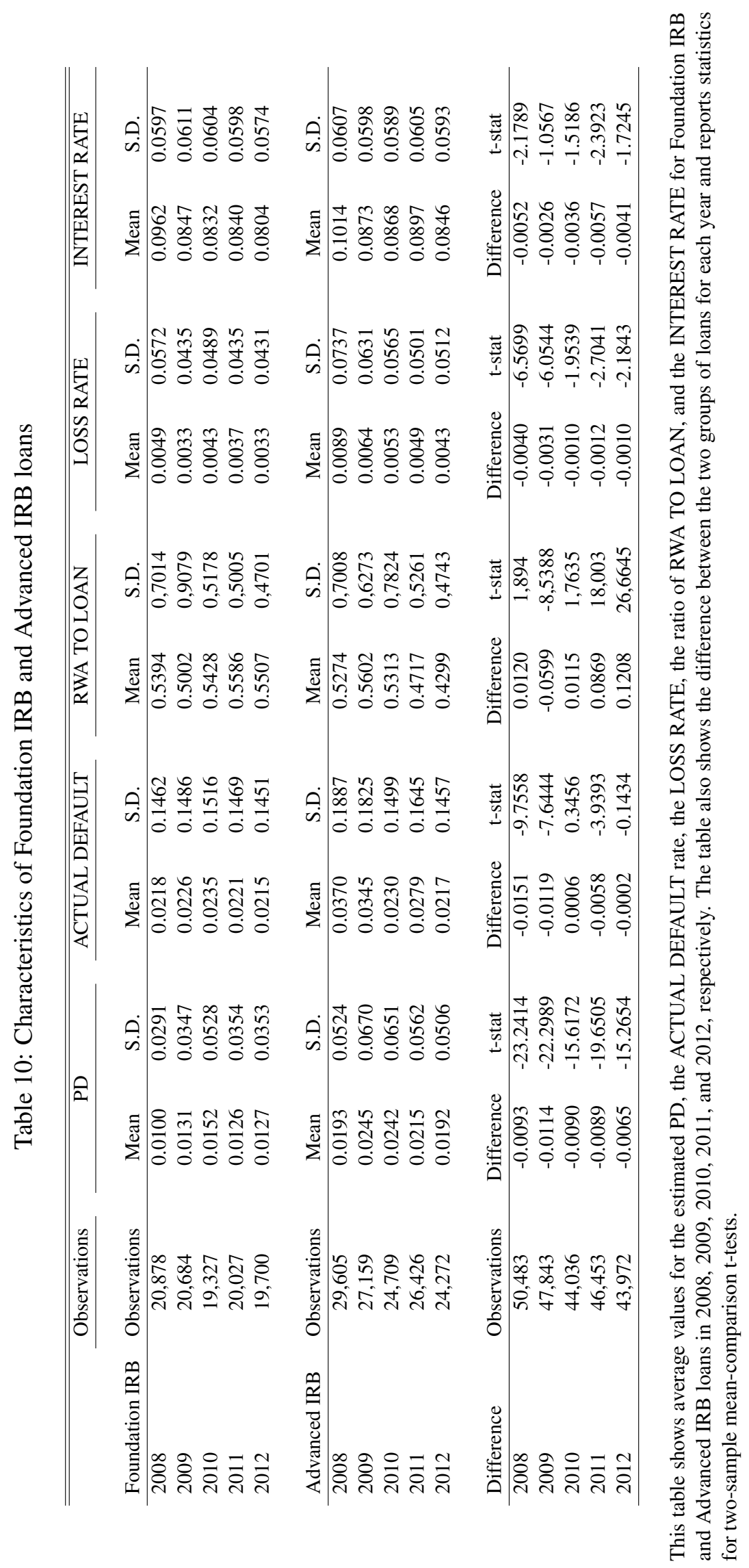


Table 11: Lending around the reform

\begin{tabular}{|c|c|c|c|c|c|c|}
\hline \multirow[t]{2}{*}{ Dependent variable: } & \multicolumn{2}{|c|}{ 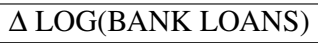 } & \multicolumn{4}{|c|}{$\Delta \mathrm{LOOG(LOANS)}$} \\
\hline & (1) & (2) & (3) & (4) & (5) & (6) \\
\hline D(IRB BANK) & $\begin{array}{c}0.0867 * * \\
(0.0346)\end{array}$ & $\begin{array}{c}0.1115^{* *} \\
(0.0505)\end{array}$ & $\begin{array}{c}0.0562 * * * \\
(0.0181)\end{array}$ & $\begin{array}{c}0.0511 * * * \\
(0.0193)\end{array}$ & & \\
\hline $\mathrm{D}(\mathrm{IRB}$ BANK $) \times$ FIRM PD & & & $\begin{array}{c}-0.5740 * * * \\
(0.1473)\end{array}$ & $\begin{array}{c}-0.5519 * * * \\
(0.1580)\end{array}$ & $\begin{array}{c}-0.4529 * * * \\
(0.1434)\end{array}$ & $\begin{array}{c}-0.3951 * * \\
(0.1573)\end{array}$ \\
\hline FIRM PD & & & $\begin{array}{c}-0.2615 * * * \\
(0.0811)\end{array}$ & & $\begin{array}{c}-0.2990 * * * \\
(0.0890)\end{array}$ & \\
\hline LOG BANK ASSETS & & $\begin{array}{c}0.0073 \\
(0.0086)\end{array}$ & & & & \\
\hline BANK EQUITY RATIO & & $\begin{array}{l}0.0067 * \\
(0.0039)\end{array}$ & & & & \\
\hline BANK ROA & & $\begin{array}{c}0.0498 * * \\
(0.0239)\end{array}$ & & & & \\
\hline D(STATE BANK) & & $\begin{array}{c}-0.0772 * * \\
(0.0355)\end{array}$ & & & & \\
\hline D(COOPERATIVE BANK) & & $\begin{array}{c}0.0461 \\
(0.0345)\end{array}$ & & & & \\
\hline Constant & $\begin{array}{c}0.1901 * * * \\
(0.0096)\end{array}$ & $\begin{array}{l}-0.0411 \\
(0.1856)\end{array}$ & $\begin{array}{c}0.0286 * * * \\
(0.0068)\end{array}$ & & & \\
\hline Firm FE & NO & NO & NO & YES & NO & YES \\
\hline Bank FE & NO & NO & NO & NO & YES & YES \\
\hline Observations & 1,603 & 1,547 & 44,784 & 44,784 & 44,784 & 44,784 \\
\hline R-squared & 0.0015 & 0.0336 & 0.0041 & 0.2271 & 0.0402 & 0.2626 \\
\hline
\end{tabular}

The dependent variable in columns 1 and 2 is the change in the logarithm of aggregate bank lending over the Basel II introduction in 2007Q1. For each bank, we calculate aggregate lending by summing all loans in a respective period. We then collapse all quarterly data for a given bank into single pre-event and post-event periods by taking the average of the two years before and the two years after the Basel II introduction. The dependent variable in the regressions above is the difference in the logarithm of these averages, so that there is one observation per bank. The dummy variable $\mathrm{D}$ (IRB BANK) indicates whether the respective bank adopted the Basel II internal ratings-based approach during our sample period. Columns 3-6 show results on the loan level. For each bank-firm relationship, we collapse all quarterly data into single pre-event and post-event periods by taking the average of the two years before and the two years after the Basel II introduction. The dependent variable in the regressions above is the difference in the logarithm of these averages, so that there is one observation per bank-firm relationship. Data are restricted to (a) loans that are larger than $€ 1.5$ million (b) loans from commercial, state, or cooperative banks that are subject to the Basel II capital regulation (c) loans that have an observation in both the pre- and the post-event period (d) loans to firms that have at least one loan from an SA bank and one loan from an IRB bank. FIRM PD is the firm's average PD in 2008Q1, the first quarter for which this information is available. Robust standard errors adjusted for clustering at the firm and bank level are reported in parentheses. Note: * indicates statistical significance at the $10 \%$ level, ** at the $5 \%$ level and *** at the $1 \%$ level. 


\section{Appendix A: Computation of Interest Rates}

Combining the quarterly Bundesbank credit register with annual firm-level accounting information from USTAN allows us to back out effective annual interest rates on the loan contract level.

Step 1: As a first step, we use quarterly information from the credit register on the bank-firm relationship level to identify individual loan contracts. From the repayment structure of the initial loan amount, we can infer the maturity of the loan contract (e.g., whether it is repaid at the end of the contract period; linearly or de/progressively). If the outstanding loan of a lending relationship increases, we identify a new loan contract. Some lending relationships include a current account for the client with a loan amount that fluctuates around a fairly stable mean. Therefore, we only identify a new loan contract if the increase in total loans per firm-bank relationship exceeds 33.33 percentage points. Following this procedure, we extract all individual loan contracts per firm from the credit register (see Table A.1, Panel A). ${ }^{35}$

To match loan and balance sheet data, we annualize the loan data by averaging the loan amount over four quarters $\left(\right.$ December $_{t-1}$, March $_{t}$, June $_{t}$, September ${ }_{t}$ ). We match contract-level information with interest payments derived from balance sheet information ${ }^{36}$ (see Table A.1, Panel B). In rare cases, firms have interest-relevant debt in excess of bank loans. In this case, the sum of all bank loans from the credit register does not sum up to the amount of loans reported in a firm's balance sheet. We deal with this discrepancy by treating the difference as an additional lending relationship.

Step 2: The combination of both datasets allows us to compute contract-level interest rates by solving the equation system:

$$
\begin{aligned}
r_{j t}= & \sum_{d=1}^{D} \frac{x_{d j t}}{\sum_{d=1}^{D} x_{d j t}} \cdot r_{d j}, \\
& \quad \text { for } t=t-\operatorname{int}(D / 2), \ldots, t, \ldots, t+\operatorname{int}((D-1) / 2),
\end{aligned}
$$

where $D$ is the number of relationships. The variable $r_{j t}$ is the average interest rate paid by firm $j$ in year $t$. We winsorize firm-level interest rates at the 5/95 percent quintile to account for unduly extreme outliers. The individual contract volume for firm $j$ 's contracts is denoted by $x_{d j t}$, and thus,

\footnotetext{
${ }^{35}$ The tables in this section help to guide the reader through the computation of interest rates by illustrating one hypothetical example.

${ }^{36}$ Annual firm-level interest rates are defined as interest expenses minus interest expenses to related firms (ap174ap175), divided by the average loan amount in the same year.
} 
$\frac{x_{d j t}}{\sum_{d=1}^{D} x_{d j t}}$ is contract $d$ 's share in firm $j$ 's total borrowing. The variable of interest is $r_{d j}$, the interest rate on the individual loan contract. ${ }^{37}$

Each contract can either be a fixed or floating rate contract. ${ }^{38}$ Equation system (A.1) can also be solved for floating rate contracts by replacing $r_{d j}$ by $\left(s_{d j}+E U R I B O R_{t}\right)$, where $s_{d j}$ is the spread over the EURIBOR for contract $d$. As we do not have information about the type of contract, we allow all possible combinations for each firm at every point in time. For a firm with $D$ contracts at a given point in time, we solve $2^{\mathrm{D}}$ different equation systems. Additionally, for $D$ contracts to solve the equation system for $r_{d j}, D$ independent equations are required. Solving the equation system provides us with contract-specific interest rates/spreads (see Table A.2).

Step 3: To identify the correct combination of contract types, we first calculate the average absolute deviation from the mean interest rate/spread for each contract:

$$
\sigma_{d j t}=\frac{1}{T} \cdot \sum_{t=1}^{T}\left|r_{d j t}-\sum_{t=1}^{T} \frac{r_{d j t}}{T}\right|
$$

where $\mathrm{T}$ is the maturity of contract $d$ in years. Next, we compute the average deviation for each of the $2^{\mathrm{D}}$ equation systems as the average deviation over all contracts as $\varsigma_{j}$. For each firm, we pick the combination of fixed and floating rate contracts that leads to the lowest value of $\varsigma_{j}$ (see Table A.2). Finally, we calculate the annual firm-bank relationship level interest rate as the valueweighted interest rate of all contracts of a firm-bank relationship for a given year. This approach allows us to compute firm-bank level interest rates for a subsample of lending relationships for which equation system (A.1) is solvable.

\footnotetext{
${ }^{37}$ In the example from Table A.1, the equation system for the year 2000 with fixed interest rates is: $\left[\begin{array}{l}0.0853 \\ 0.0803\end{array}\right]=\left[\begin{array}{cc}1 & 0 \\ 0.1765 & 0.8235\end{array}\right] \times\left[\begin{array}{l}r_{1} \\ r_{2}\end{array}\right]$

${ }^{38}$ In Germany, floating rate contracts use the EURIBOR as of 1999.
} 
Table A.1: Contract Extraction

\begin{tabular}{cccccc}
\hline \hline $\begin{array}{c}\text { A - Quarterly Data } \\
\text { Quarter }\end{array}$ & $\begin{array}{c}\text { I } \\
\text { Bank A }\end{array}$ & $\begin{array}{c}\text { II } \\
\text { Bank B }\end{array}$ & $\begin{array}{c}\text { III } \\
\text { Contract 1 (A) }\end{array}$ & $\begin{array}{c}\text { IV } \\
\text { Contract 2 (A) }\end{array}$ & $\begin{array}{c}\text { V } \\
\text { Contract 3 (B) }\end{array}$ \\
\hline 1998 Q4 & 12000 & - & 12000 & - & - \\
1999 Q1 & 10000 & - & 10000 & - & - \\
1999 Q2 & 8000 & - & 8000 & - & - \\
1999 Q3 & 6000 & - & 6000 & - & - \\
1999 Q4 & 11000 & - & 4000 & 7000 & - \\
2000 Q1 & 9000 & - & 2000 & 7000 & - \\
2000 Q2 & 7000 & - & - & 7000 & - \\
2000 Q3 & 7000 & - & - & 7000 & - \\
2000 Q4 & 7000 & - & - & 7000 & - \\
2001 Q1 & 7000 & - & - & 7000 & - \\
2001 Q2 & 7000 & - & - & 7000 & - \\
2001 Q3 & 7000 & 5000 & - & 7000 & 5000 \\
2001 Q4 & - & 4000 & - & - & 4000 \\
2002 Q1 & - & 3000 & - & - & 3000 \\
2002 Q2 & - & 2000 & - & - & 2000 \\
2002 Q3 & - & 1000 & - & - & 1000 \\
\hline \hline B - Annualized Data & I & II & III & IV & V \\
Year & IR & Spread & Contract 1 (A) & Contract 2 (A) & Contract 3 (B) \\
\hline 1999 & 0.0700 & 0.0381 & 9000 & - & - \\
2000 & 0.0853 & 0.0367 & 1500 & 7000 & - \\
2001 & 0.0803 & 0.0399 & - & 7000 & 1250 \\
2002 & 0.0800 & 0.0451 & - & - & 2500 \\
\hline \hline
\end{tabular}

Panel A of this table lists a firm's total loans from Bank A in column I and Bank B in column II, derived from the credit register. Columns III to V display the contracts extracted from the quarterly loan information. Panel B depicts the annualized data. Column I shows the annual firm-level interest rate from balance sheet data, and column II the spread of the interest rate over the EURIBOR. Columns III to V list the average annual loan for Contracts 1 to 3 . Details on the identification of loan contracts can be found in the text. 
Table A.2: Solutions

\begin{tabular}{|c|c|c|c|c|c|c|c|c|}
\hline & $(\mathrm{r}, \mathrm{r}, \mathrm{r})$ & $(\mathrm{s}, \mathrm{s}, \mathrm{s})$ & $(\mathrm{r}, \mathrm{s}, \mathrm{s})$ & $(\mathrm{r}, \mathrm{r}, \mathrm{s})$ & $(\mathrm{r}, \mathrm{s}, \mathrm{r})$ & $(\mathrm{s}, \mathrm{r}, \mathrm{r})$ & $(\mathrm{s}, \mathrm{r}, \mathrm{s})$ & $(\mathrm{s}, \mathrm{s}, \mathrm{r})$ \\
\hline \multicolumn{9}{|l|}{$\underline{1999}$} \\
\hline Contract 1 (A) & 0.0700 & 0.0381 & 0.0700 & 0.0700 & 0.0700 & 0.0381 & 0.0381 & 0.0381 \\
\hline Contract 2 (A) & - & - & - & - & - & - & - & - \\
\hline Contract 3 (B) & - & - & - & - & - & - & - & - \\
\hline \multicolumn{9}{|l|}{2000} \\
\hline 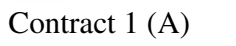 & 0.0700 & 0.0381 & 0.0700 & 0.0700 & 0.0700 & 0.0381 & 0.0381 & 0.0381 \\
\hline Contract 2 (A) & 0.0886 & 0.0364 & 0.0400 & 0.0886 & 0.0400 & 0.0850 & 0.0850 & 0.0364 \\
\hline Contract 3 (B) & - & - & - & - & - & - & - & - \\
\hline \multicolumn{9}{|l|}{$\underline{2001}$} \\
\hline 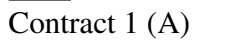 & 0.0700 & 0.0381 & 0.0700 & 0.0700 & 0.0700 & 0.0381 & 0.0381 & 0.0381 \\
\hline Contract 2 (A) & 0.0886 & 0.0364 & 0.0400 & 0.0886 & 0.0400 & 0.0850 & 0.0850 & 0.0364 \\
\hline Contract 3 (B) & 0.0339 & 0.0595 & 0.0395 & -0.0065 & 0.0799 & 0.0540 & 0.0136 & 0.0999 \\
\hline \multicolumn{9}{|l|}{$\underline{2002}$} \\
\hline 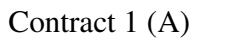 & - & - & - & - & - & - & - & - \\
\hline Contract 2 (A) & 0.0804 & 0.0390 & 0.0390 & 0.0794 & 0.0400 & 0.0804 & 0.0794 & 0.0462 \\
\hline Contract 3 (B) & 0.0800 & 0.0451 & 0.0451 & 0.0451 & 0.0800 & 0.0800 & 0.0451 & 0.0451 \\
\hline $\bar{\sigma} \sigma($ Contract $1(\mathrm{~A}))$ & 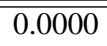 & 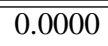 & 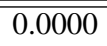 & 0.0000 & 0.0000 & 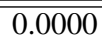 & 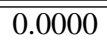 & 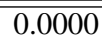 \\
\hline$\sigma($ Contract $2(\mathrm{~A}))$ & 0.0101 & 0.0031 & 0.0012 & 0.0113 & 0.0000 & 0.0057 & 0.0069 & 0.0120 \\
\hline$\sigma($ Contract $3(\mathrm{~B}))$ & 0.0345 & 0.0108 & 0.0042 & 0.0387 & 0.0001 & 0.0195 & 0.0236 & 0.0411 \\
\hline$\varsigma$ & 0.0149 & 0.0046 & 0.0018 & 0.0166 & 0.0000 & 0.0084 & 0.0102 & 0.0177 \\
\hline
\end{tabular}

The first line of this table indicates the combination of fixed rate contracts (r) and floating rate contracts (s). The optimal combination of contracts to solve the equation system is (r,s,r). The interest rate for Contract 1 is 0.08 , the spread for Contract 2 is 0.04 , and the interest rate for Contract 3 is 0.07 . This leads to annual interest rates of 0.0700 in $1999,0.0853$ in 2000, and 0.0804 in 2001 for Bank A, and 0.0800 in 2001 and 2002 for Bank B. 